\title{
norden
}

\section{The Cost of Inaction}

A socioeconomic analysis of costs linked to effects of endocrine

disrupting substances on male reproductive health

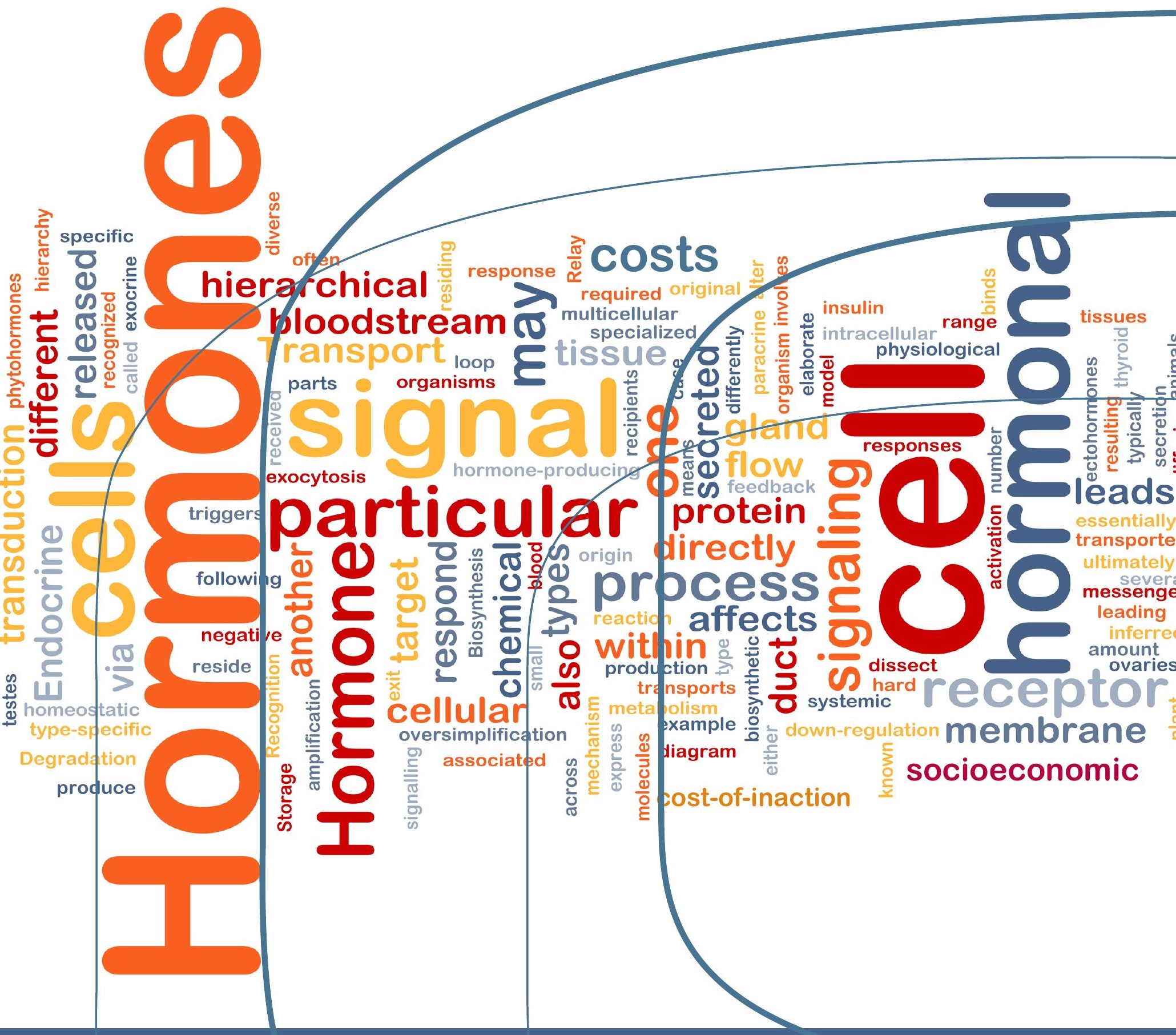



2 norden 



\section{The Cost of Inaction}

- A Socioeconomic analysis of costs linked to effects of endocrine disrupting substances on male reproductive health

Ing-Marie Olsson et al. 
The Cost of Inaction

- A Socioeconomic analysis of costs linked to effects of endocrine

disrupting substances on male reproductive health

Ing-Marie Olsson m.fl.

ISBN 978-92-893-3828-8 (PRINT)

ISBN 978-92-893-3830-1 (PDF)

ISBN 978-92-893-3829-5 (EPUB)

http://dx.doi.org/10.6027/TN2014-557

TemaNord 2014:557

ISSN 0908-6692

(C) Nordic Council of Ministers 2014

Layout: Hanne Lebech

Cover photo: Signelements

Print: Rosendahls-Schultz Grafisk

Printed in Denmark

This publication has been published with financial support by the Nordic Council of Ministers. However, the contents of this publication do not necessarily reflect the views, policies or recommendations of the Nordic Council of Ministers.

\section{www.norden.org/en/publications}

\section{Nordic co-operation}

Nordic co-operation is one of the world's most extensive forms of regional collaboration, involving Denmark, Finland, Iceland, Norway, Sweden, and the Faroe Islands, Greenland, and Åland.

Nordic co-operation has firm traditions in politics, the economy, and culture. It plays an important role in European and international collaboration, and aims at creating a strong Nordic community in a strong Europe.

Nordic co-operation seeks to safeguard Nordic and regional interests and principles in the global community. Common Nordic values help the region solidify its position as one of the world's most innovative and competitive.

\section{Nordic Council of Ministers}

Ved Stranden 18

DK-1061 Copenhagen K

Phone (+45) 33960200

\section{www.norden.org}




\section{Content}

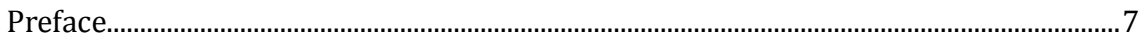

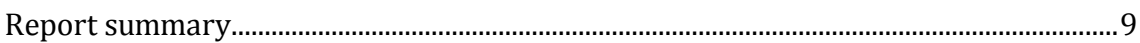

1. Endocrine disruptors - focus on effects on male reproductive health..................... 15

1.1 What is an endocrine disruptor? ................................................................... 15

1.2 Suspected effects of exposure to endocrine disruptors................................. 15

1.3 Linking exposure of endocrine disruptors to effects on male reproductive health ........................................................................................ 18

1.4 Widespread occurrence of endocrine disruptors ........................................... 22

1.5 The importance of regulating endocrine disruptors, including the development of strict scientifically based criteria .......................................... 24

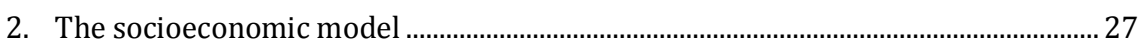

2.1 Overall method .................................................................................................. 27

$2.2 \quad$ Uncertainties in cost of illness estimates......................................................... 34

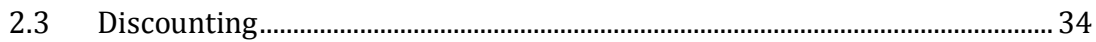

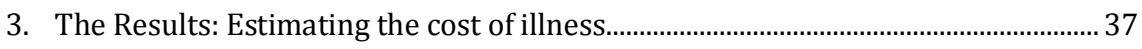

3.1 Testicular cancer.................................................................................................. 37

3.2 Infertility due to low semen quality............................................................ 42

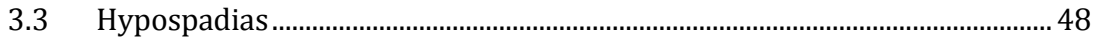

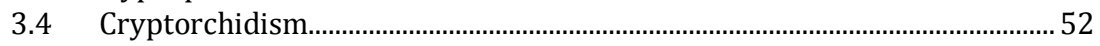

3.5 Estimating the costs in the Nordic countries.................................................. 55

3.6 Estimating the costs in the EU-28............................................................. 57

3.7 Discussion on uncertainty - sensitivity analysis............................................ 60

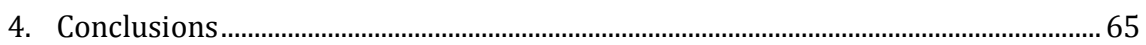

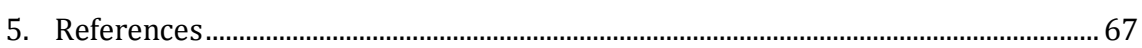

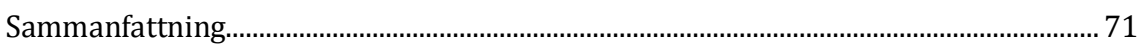

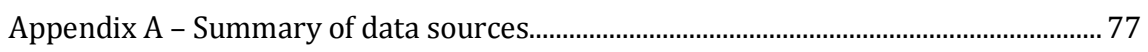

Appendix B - Treatment schemes..................................................................................... 79

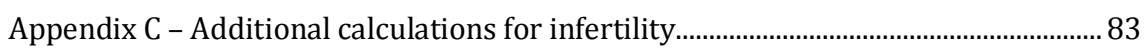

Appendix D - Estimated costs per Nordic country and EU-28 …..................................... 87

List of abbreviations..................................................................................................... 89 



\section{Preface}

\section{Purpose of this report}

The purpose of this report is to estimate the costs for society related to negative effects on human male reproductive health suspected to be linked to exposure to endocrine disruptors.

\section{Disposition}

The report is divided into three main parts. The first chapter outlines strength of the evidence of a link between negative effects on male reproductive health and endocrine disrupting substances. In the second chapter the overall model for estimating the costs of endocrine disruptors is presented. In the third chapter, estimations of costs and incidences related to effects on human male reproductive health induced by endocrine disruptors are presented. Towards the end of the last chapter, the overall cost estimates along with a sensitivity analysis of these estimates are also presented.

\section{Scope and limitations}

Exposure to endocrine disruptors is suspected to lead to a number of negative effects on human health and for wildlife, including decreased fertility, increased occurrence of hormonally-related cancers, behavioral changes, metabolic disorders like obesity and diabetes and suppression of the immune system.

However, the scientific evidence of a causal link between exposure and negative effects is not equally strong in all cases. In the present report, we have focused on negative effects on humans for which the causal link between exposure to endocrine disruptors and negative effects is relatively well established, i.e. negative effects on male reproductive health (cryptorchidism, hypospadias, poor semen quality and testicular germ cell cancer). It must be acknowledged that the costs estimated in this report therefore represent only a fraction of the total costs of exposure to endocrine disruptors.

The strength of the evidence between exposure to endocrine disruptors and the effects on male reproductive health seems convincing when 
the biological plausibility is combined with human epidemiological and case studies, effects observed in wildlife and effects observed in laboratory animals exposed to endocrine disruptors. It is, however, not the focus of the present report to document the strength of the evidence. That exposure to endocrine disruptors leads to negative health effects in human populations is thus a basic assumption of this report, and for discussions of the strength of the evidence, reference is made to major review reports within the field, including the State of the science of endocrine disrupting chemicals (WHO/UNEP 2012) and State of the art assessment of endocrine disruptors (Kortenkamp et al. 2012).

Throughout the paper we discuss costs of illness which is the same as the monetary benefit of reducing risks. The cost estimates in this report are mainly valid for the Nordic countries and extrapolation of these results to other countries, including EU-28, is associated with increasing uncertainty.

\section{Financing and work force}

The health economic models and calculations have been developed and described by Karl Kjäll and Andreas Pistol, Ramböll. The socioeconomic part of the project has been funded by the Nordic Council of Ministers.

The steering group for the project, financed by respective agencies, (Marie Louise Holmer, Danish Environment Protection Agency, Helena Niemelä and Juha Laakso, Finnish Safety and Chemicals Agency, Christine Bjørge and Kenneth Birkeli, Norwegian Envrionmental Agency, Mattias Carlsson and Ing-Marie Olsson, Swedish Chemicals Agency) have been responsible for the part on endocrine disrupting substances and for editing and finalising the socioeconomic part and the report in general. Marie Louise Holmer and Mattias Carlsson have been the steering group's main authors and editors.

\section{Acknowledgments}

We highly appreciate the contributions made to this work by Gunnar Brunborg and Birgitte Lindeman, Norweigian Institute of Public Health, Sophie Dorothea Fosså, Oslo University Hospital, Ulla Hass, Technical University of Denmark, Anders Juul, Kristian Almstup and Niels-Erik Skakkebæk, Copenhagen University Hospital Rigshospitalet, Jorma Toppari, University of Turku, Göran Westlander, Carlanderska hospital Gothenburg, Agneta Nordenskjöld, Claude Kollin, and Olle Söder, Karolinska University Hospital, Solna. 


\section{Report summary}

Exposure to endocrine disruptors is suspected to lead to a number of negative effects on human health and for wildlife, including decreased fertility, increased occurrence of hormonally-related cancers, behavioral changes, metabolic disorders like obesity and diabetes and suppression of the immune system. Such negative effects cause not only distress and pain for the persons (and the wildlife) affected, treatment of these effects also causes economic costs not only for those affected, but also for society in general. The purpose of the present report is therefore to provide a first estimate of societal costs of the consequences of exposure to endocrine disruptors to the extent possible.

However, the scientific evidence of a causal link between exposure and negative effects is not equally strong in all cases. In the present report, we have focused on negative effects on humans for which the causal link between exposure to endocrine disruptors and negative effects is relatively well established, i.e. negative effects on male reproductive health (cryptorchidism, hypospadias, poor semen quality and testicular germ cell cancer). It must be acknowledged that the costs estimated in this report therefore represent only a fraction of the total costs of exposure to endocrine disruptors.

The strength of the evidence between exposure to endocrine disruptors and the effects on male reproductive health seems convincing when the biological plausibility is combined with human epidemiological and case studies, effects observed in wildlife and effects observed in laboratory animals exposed to endocrine disruptors. That exposure to endocrine disruptors leads to negative health effects in human populations is thus a basic assumption of this report. It has not been the focus of the present project to document the causal links.

In order to estimate the costs related to effects of the current exposure to endocrine disruptors on male reproductive health, incidence figures for the illnesses in focus (testicular cancer, infertility (due to low semen quality), hypospadias and cryptorchidism) have been derived 
from different sources, and this information has been combined with assumptions of the etiological fraction. ${ }^{1}$

The incidence of different types of cancer is well monitored throughout the Nordic countries (through the Nordic Cancer Registry, Nordcan 2014), but when it comes to the incidence of the other illnesses, different methods for estimating incidence have been used. Some are based on registry studies and some on earlier scientific works.

Although the strength of the evidence between exposure to endocrine disruptors and effects on male reproductive health seems convincing, it is difficult to estimate the etological fraction (the fraction of incidences assumed to be caused by exposure to endocrine disruptors). Therefore, based on the available knowledge, and after consultation with experts, we use three estimates of etiological fraction for comparison in this report. These are $2 \%, 20 \%$ and $40 \%$.

\section{Estimating the costs to society - Nordic Countries (Denmark, Finland, Iceland, Norway and Sweden)}

The total cost estimates include direct tangible costs (costs of treatment in the health care system), indirect tangible costs (e.g. from sickness leave from work) and intangible costs (loss of life years and loss of quality of life). However, in the cost estimates for infertility due to reduced semen quality, intangible costs are not included due to difficulties in finding reliable sources that quantify these aspects.

The direct and indirect costs have been discounted by a rate of $4 \%$ per year, while the intangible costs are discounted by a pure time preference rate of $1.5 \%$ per year.

Assuming an etiological fraction of $20 \%$, the estimated cost of illness related to negative effects on male reproduction due to the present yearly exposure to endocrine disruptors in the Nordic countries is EUR 36 million per year of exposure. The intangible costs of infertility which are likely to be substantial - are not included in this estimate.

Figure 1 summarises, the estimates of the direct, indirect and intagnible costs of effects on human male reproduction in the Nordic countries.

The estimated costs are discounted values; the undiscounted costs (which quantify the costs today arising from past exposure) are more

\footnotetext{
1 The fraction of the total number of cases caused by exposure to a specific factor, in this report endocrine disruptors.
} 
than twice as high. At an etiological fraction of $20 \%$, the total undiscounted costs of yearly exposure are estimated to be EUR 77 million in the Nordic countries.

Figure 1 - Cost of effects on human male reproduction in the Nordic countries due to endocrine disruptors at different levels of assumed etiological fractions (millions of EUR per year of exposure)

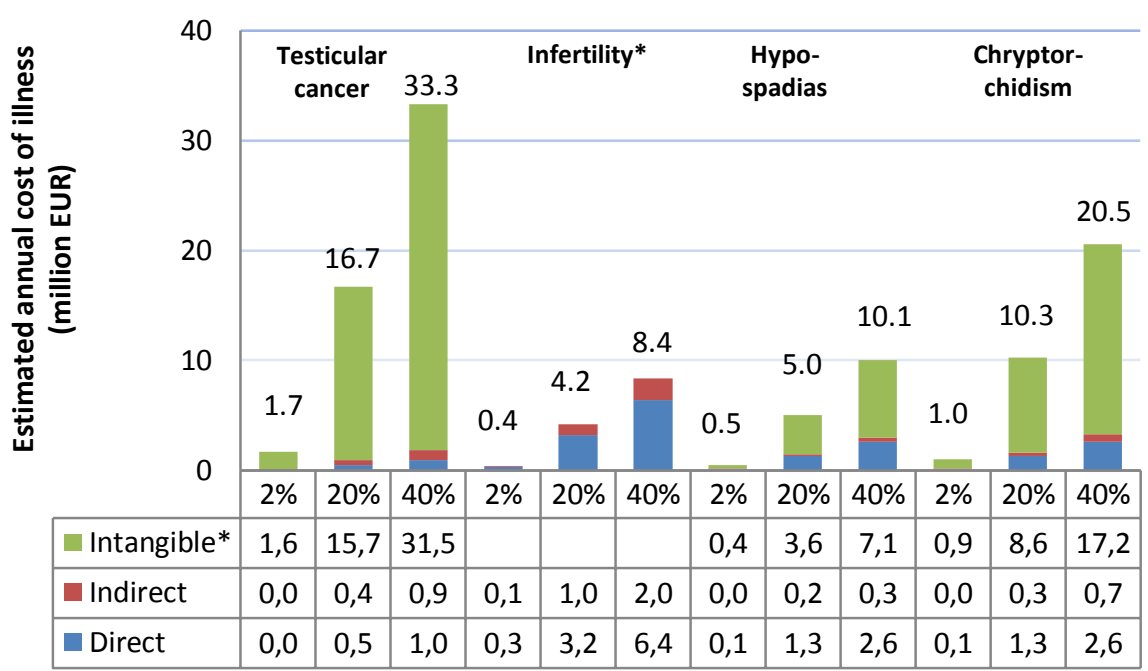

*Intangible costs of infertility are not quantified in this report.

\section{Estimating the costs to society - EU-28}

While estimating the socio-economic costs for the Nordic countries we have also made some simple extrapolations to estimate the equivalent costs in the EU assuming that the numbers of incidences of the different relevant health effects also in the next 30 years will be the same as today.

By further assuming an etiological fraction of $20 \%$ the discounted socio-economic costs due to yearly exposure to endocrine disruptors would be EUR 592 million in the EU-28 (Figure 2). Assuming another etiological fraction than $20 \%$ will change the results above proportionally. An etiological fraction of $2 \%$ yields a total cost of EUR 59 million per year of exposure in the EU-28 while an etiological fraction of $40 \%$ implies costs of nearly EUR 1,200 million per year of exposure (Figure 2)

The undiscounted costs (which quantify the costs today arising from past exposure) are more than twice as high as the discounted estimates above. At an etiological fraction of $20 \%$, the total undiscounted costs in EU-28 are estimated to be EUR 1,267 million per year of exposure to endocrine disruptors. 
Figure 2- Cost of effects on human male reproduction in the EU-28 due to endocrine disruptors at different levels of assumed etiological fractions (millions of EUR per year of exposure)

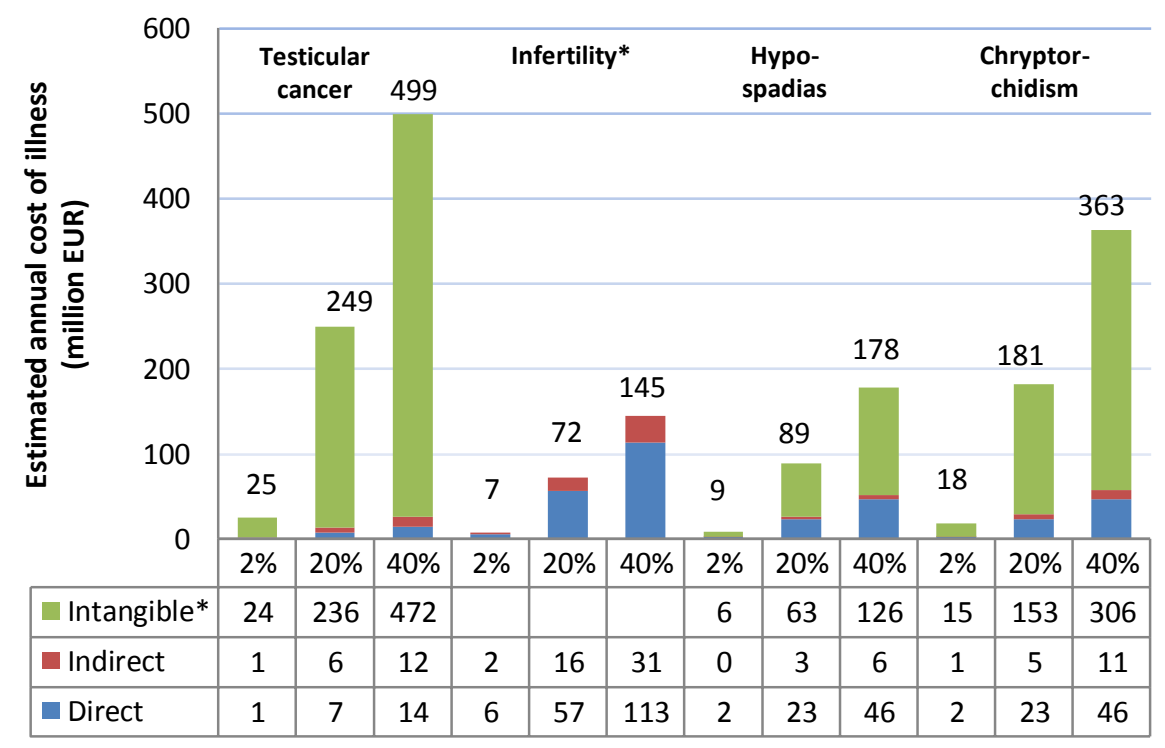

*The intangible costs of infertility are not quantified in this report.

\section{Conclusions}

The overall estimates of the cost of illness related to negative effects on human male reproduction due to the current yearly exposure to endocrine disruptors in the Nordic countries (Denmark, Finland, Iceland, Norway and Sweden) amounts to approximately EUR 36 million given that $20 \%$ of cases are due to exposure to endocrine disruptors. If the low etiological fraction (2\%) is assumed, the total costs in the Nordic countries amounts to approximately EUR 3.6 million per year of eaxposure, and if the high etiological fraction (40\%) is assumed, the total costs amounts to EUR 73 million per year of exposure. These estimates include intangible costs of all diseases except infertility (due to the high degree of uncertainty of this estimate). The total estimated costs are therefore most probably underestimated.

Extrapolated to the EU-28, the cost could amount to nearly EUR 600 million per year of exposure using the etiological fraction of $20 \%$ (EUR 59 million per year using the etiological fraction of $2 \%$ and nearly EUR 1,200 million per year using an etiological fraction of 40\%). The estimates for EU-28 are to a large degree extrapolation of estimated results from the Nordic countries and therefore more uncertain than the results for the Nordic countries. 
The undiscounted costs (which quantify the costs today arising from past exposure) are more than twice as high as the discounted estimates above. At an etiological fraction of $20 \%$, the total undiscounted costs in the Nordic countries are estimated to be EUR 77 million, and in EU-28 EUR 1,267 million per year of exposure to endocrine disruptors.

It should be kept in mind that this report focuses on only a small part of the various negative health effects, which have been linked to exposure to endocrine disruptors. If the costs related to effects in wildlife, increased occurrence of other hormonally-related cancers (e.g. breast and prostate cancer), other hormonal diseases like polycystic ovarie syndrome and other female reproductive disorders, behavioral changes, metabolic disorders like obesity and diabetes and suppression of the immune system were added, the costs related to exposure to endocrine disruptors would be much higher than estimated in this report. Recently the costs of exposure to endocrine disruptors have been estimated to EUR 31 billion per year in EU (HEAL 2014). Since the HEAL estimate is focussing on the cost today arising from former exposure it is not discounted. Furthermore, it includes costs related to treatment of human infertility, cryptorchidism, hypospadias, breast cancer, prostate cancer, ADHD, autism, overweight, obesity, and diabetes, assuming an etiological fraction of 2-5\% (HEAL, 2014). Even though there are differences in the assumptions between this report and the report from HEAL, the estimated costs related to male reproductive health are roughly similar. According to the HEAL report it is only $0.5-0.7 \%$ out of the EUR 31 billion per year that is related to human infertility, cryptorchidism and hypospadias. This further emphasises that the figures in this report only show a fraction of the total costs related to endocrine disruptors.

Assuming that endocrine disruptors lead to a number of negative effects on human health and for wildlife, this report substantiate that minimizing exposure to endocrine disruptors will not only remove distress and pain for the persons (and the wildlife) affected, it will also save the society from considerable economic costs. Some of the steps that could lead to reduced exposure to substances with these effects are 1) development of strict scientifically based criteria for the identification of endocrine disruptors and implementation of these in relevant EU legislation, 2) enhancement of the standard information requirements in relevant EU legislation to also comprise information on endocrine disruptive properties, 3) screening of substances for suspected endocrine disrupting properties based on available data, 4) specific testing of suspected endocrine disruptors in order to assess their endocrine disrupting potential, and 5) regulation aimed at minimizing exposure to identified endocrine disruptors. 



\section{Endocrine disruptors - focus on effects on male reproductive health}

The focus in this chapter is on the various negative health effects that may be induced by exposure to endocrine disruptors. This is followed by a review of the strength of the evidence that links exposure to endocrine disruptors to negative effects on human male reproductive health. Thereafter, the widespread occurrence of endocrine disruptors and the importance of regulating these substances, including the development of strict scientifically based criteria, are highlighted.

\subsection{What is an endocrine disruptor?}

While awaiting EU criteria for the identification of endocrine disruptors, the "working definition" of WHO/IPCS has been applied in this report:

"...an exogenous substance or mixture that alters function(s) of the endocrine system and consequently causes adverse health effects in an intact organism, or its progeny, or (sub) populations."

WHO/IPCS 2002

\subsection{Suspected effects of exposure to endocrine disruptors}

Exposure to endocrine disruptors may lead to a number of negative effects on human health and on wildlife, including reduced fertility, occurrence of hormonally-related cancers and other diseases, behavioral changes, effects on the nervous system, metabolic disorders like obesity and diabetes and suppression of the immune system. During the last decade the scientific understanding of the relationship between exposure to endocrine disruptors and effects on human health has advanced rapidly. There is a growing concern that exposure to endocrine disrup- 
tors in fetal life and childhood plays a larger role in the development of endocrine diseases and disorders than previously anticipated. This is supported by observations in wildlife, by studies in laboratory animals, and by the fact that the observed increased incidence and prevalence of several endocrine disorders cannot be explained by genetic factors alone (WHO/UNEP, 2012).

The main focus regarding endocrine disruption was initially on the action of sex hormones (androgens and oestrogens). In recent years, more and more attention has been drawn to other pathways regulated by hormones, e.g. the pathways involving thyroid hormones, corticosteroids, growth hormone, Vitamin A and vitamin D (See figure 3) (OECD, 2012). Different endocrine disruptors can affect the synthesis, metabolism and action of numerous different hormones and pathways, as illustrated in figure 3, leading to various effects on metabolism, reproduction, growth and development of the organism. It should furthermore be kept in mind that a single endocrine disruptor can affect multiple hormonal pathways, leading to a number of different effects in the exposed organism.

Figure 3 - Examples of hormonal pathways that can be affected by endocrine disruptors, resulting in symptoms of metabolic syndrome and disruptions in reproduction, growth and development

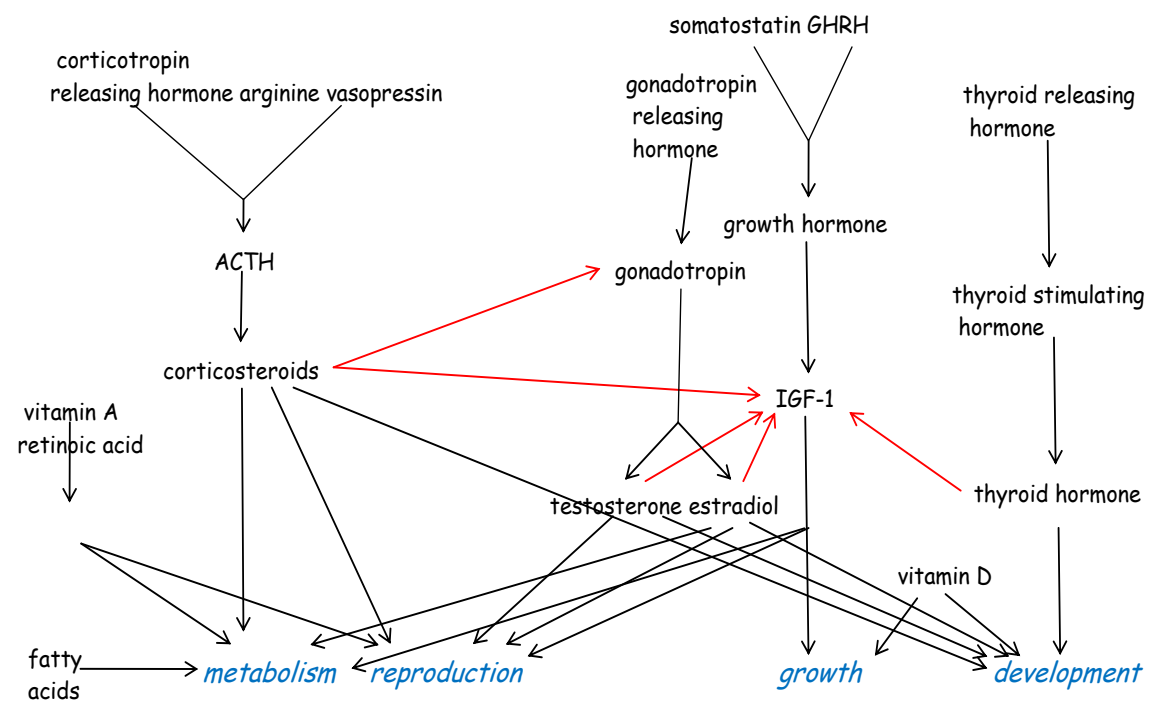

Source: OECD (2012). Note: Black arrows denote contiguous pathways, red arrows highlight examples of cross-talk between pathways. 
Taken together, the disruption of these pathways can lead to a wide variety of effects on metabolism, reproduction, growth and development. A detailed OECD review from 2012 highlights this as follows:

\begin{abstract}
"Human populations have experienced increases in various disorders, such as obesity; diabetes; hyperlipidemia; cardiovascular disease; metabolic syndrome; reproductive disorders such as infertility; autism; and attention deficit hyperactivity disorder (ADHD). Many of these disorders have known or suspected environmental contributors, as well as linkages to the endocrine system. Exposure to endocrine disrupting substances has been proposed as possible contributors to their etiology..."
\end{abstract}

In the WHO/UNEP report from 2012 (WHO/UNEP, 2012), all of the following effects are linked to exposure to endocrine disruptors:

- Female reproductive health (including puberty onset, low fecundity, subfertility, infertility, adverse pregnancy outcomes, polycystic ovary syndrome, uterine fibroids and endometriosis).

- Male reproductive health (including testicular germ cell cancer, cryptorchidism, hypospadias, reduced semen quality and decreased testosterone).

- Sex ratio in humans and wildlife.

- Thyroid related disorders.

- Neurodevelopment in children and wildlife.

- Hormone related cancers (including breast, endometrial, ovarian, prostate, testis and thyroid cancer).

- Adrenal disorders in human and wildlife.

- Bone disorders.

- Metabolic disorders (including obesity and diabetes).

- Immune function, immune diseases and disorders in humans and wildlife.

- Population declines.

This list illustrates that exposure to endocrine disruptors is associated with numerous, and very different, negative effects, but the evidence of a link between exposure and effect is not equally strong in all cases. Based on an evaluation of the strength of the evidence between exposure and 
effect, negative effects on male reproductive health (cryptorchidism, hypospadias, poor semen quality and testicular germ cell cancer) were chosen as the focus area of this report. However, the costs related to male reproductive effects represent only a fraction of the total costs of endocrine disruptors.

\title{
1.3 Linking exposure of endocrine disruptors to effects on male reproductive health
}

In the WHO/UNEP report from 2012 the strength of evidence of a link between exposure to endocrine disruptors and effects on male reproductive health is summarized as follows:

\begin{abstract}
"There is sufficient evidence that male reproductive disorders originating during fetal life, are increasing in the human populations in which they have been studied, and that this is partially related to environmental exposures. These diseases include cryptorchidism (testicular non-descent), hypospadias and testis germ cell cancer. There is also limited evidence linking these diseases and disorders with specific occupations and with exposures to chemicals with endocrine disrupting properties, particularly agricultural workers (pesticides and fungicides), PBDE flame retardants and phthalate plasticizers."

"Taking the wildlife and human evidence together, there is a possibility that exposure to EDCs during fetal life and/or during puberty plays a role in the causation of male reproductive health problems in humans, in some populations."
\end{abstract}

WHO/UNEP, 2012

The strength of the evidence between exposure and effects seems convincing when the biological plausibility is combined with human epidemiological and case studies, effects observed in wildlife and effects observed in laboratory animals exposed to endocrine disruptors:

A) It is biologically plausible that exposure of males to oestrogenic or anti-androgenic substances during fetal life can lead to cryptorchidism, hypospadias, testicular cancer and reduced semen quality later in life, since testicular decent, normal development of sex organs, and development of healthy testes (not predisposed to testicular germ cell cancer or low semen quality) are all highly dependent on androgen action and a fine hormonal balance between oestrogens and androgens during sensitive periods in fetal development (WHO/UNEP, 2012). These effects on 
male reproductive health (cryptorchidism, hypospadias, reduced semen quality and testicular cancer) are risk factors for each other. It is hypothesized that they have a common origin of diminished androgen action in fetal life. They often occur together, and together they are hypothesized to comprise the testicular dysgenesis syndrome (TDS). There is not scientific agreement about this hypothesis (Akre and Richiardi, 2009), but the biological plausibility is high, and the syndrome is also hypothesized to have a strong environmental etiology with chemical exposures as an important component (Kortenkamp et al., 2012).

As illustrated in figure 4, the initiating event in the cascade that leads to testicular dysgenesis syndrome (TDS) is activation of the oestrogen receptor (ER) or suppression of hormonal action through the androgen receptor (AR) in fetal life, for example by exposure to oestrogenic or antiandrogenic substances. This leads initially to dysfunction of Sertoli cells and Leydig cells in the developing testes. Later the dysfunction of these cells in the testes can lead to reduced semen quality and testicular cancer as well as hypospadias and testicular maldescent (cryptorchidism).

Figure 4 -Proposed cascade of events leading to testicular dysgenesis syndrome

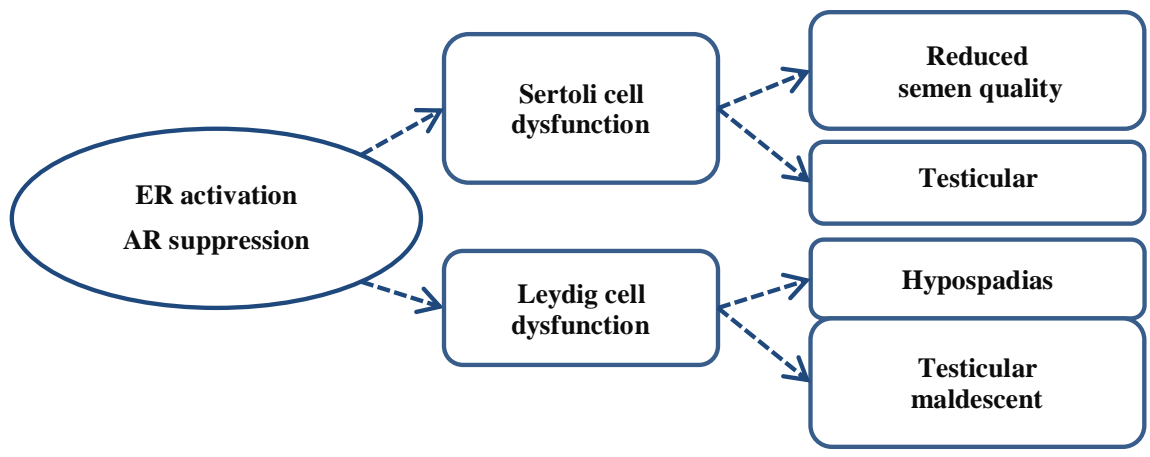

Source: OECD, 2012

B) Results from animal studies demonstrate that exposure of rodents to numerous substances, including industrial chemicals, herbicides, fungicides, insecticides and metals during fetal life can lead to adverse effects (e.g. cryptorchidism, hypospadias, reduced semen quality, reduced anogenital distance, retention of nipples) in the male offspring (OECD, 2012). Some of these effects are similar to the effects observed in human 
populations, and are consistent with the effects comprising the testicular dysgenesis syndrome (OECD, 2012).

In rodent studies it has furthermore been shown that combined exposure of pregnant dams ${ }^{2}$ to a mixture of endocrine disruptors in doses that do not cause adverse effects when given alone, can lead to marked endocrine disruptive effects in the offspring (Hass et al. 2007, Christiansen et al. 2008, Jacobsen 2012).

C) Some epidemiological studies describe increased occurrence of effects on male reproductive health (increased incidences of cryptorchidism, hypospadias and testicular germ cell cancer and low semen quality) in some human populations (WHO/UNEP, 2012). Semen quality in $40 \%$ of young Danish men is so low, they are expected either to have longer waiting time to pregnancy, or in the worst cases $(6 \%)$ not to be able to have children without clinical help , (Andersson et al., 2008). Up to 8\% of Danish children are now conceived through assisted fertilization. Furthermore, in Denmark absence of one or both testes from the scrotum in baby boys at birth has increased from $2 \%$ to $9 \%$ over the last 50 years (Boisen et al., 2004, Boisen et al., 2005), girls develop breasts one year earlier than they did 15 years ago (Aksglaede et al., 2009) and testicular cancer rates are among the highest in Europe - 1\% of all Danish men develop testicular cancer (Andersson et al., 2008, Jacobsen et al., 2006). This is not only a Danish problem. All over the world, similar trends are observed, and these changes happen so fast, that they are believed to be caused by environmental factors. Even though the above diseases are multifactorial, and other environmental factors like diet, smoking and alcohol consumption might also play a causative role in the observed increased occurrencies, scientists point to exposure to endocrine disruptors as one plausible cause of the observed effects.

Furthermore, several studies among migrants from low-incidence countries (or vice versa) have shown that the risk of testicular germ cell cancer among first-generation immigrants is the same as in their country of origin, while the risk among second-generation immigrants approaches that of their new home country (Kortenkamp et al., 2012). Such changes cannot be explained by changes in the genes, but must be due to different exposures to environmental factors, including exogenous chemical substances.

2 Dam refers to a female parent of an animal. 
Some case studies have linked exposure of pregnant women to effects in male offspring. A prominent example is the DES (diethylstilbestrol) incident, where pregnant women in the 1940s-1970s were prescribed the synthetic oestrogen DES to prevent miscarriages and other pregnancy complications. Although DES was a pharmaceutical drug given at relatively high doses, this case study illustrates the spectrum of possible effects that endocrine disrupting substances can cause when exposures occur at critical times during early development of an organism (WHO/UNEP, 2012).

Daughters of DES exposed mothers were initially found to develop a rare vaginal cancer type, and later DES was associated with reproductive problems in $90-95 \%$ of the daughters; reproductive tract malformations and dysfunction, miscarriage, preterm delivery, low birth weight, ectopic pregnancies and premature births (WHO/UNEP, 2012). Research found that in utero exposure to DES alters the normal programming of gene families that play important roles in reproductive tract differentiation. As a result, DES exposed daughters were at an increased risk for developing clear cell adenoma of the vagina and cervix, structural reproductive tract anomalies, infertility and poor pregnancy outcomes. Moreover, developmental exposures may have played a role in increased risk of adult onset of fibroids and endometriosis as well as breast cancer. The sons of exposed mothers suffer a range of reproductive problems including malformations (hypospadias, urethral abnormalities, epididymal cysts and undescended testes) and increased genital/urinary inflammation. Follow up studies of DES exposed sons have also indicated a slightly increased risk of developing testicular germ cell cancer (WHO/UNEP, 2012). In animal models, DES has furthermore been observed to induce a number of effects on reproduction in the male offspring, including sterility, reduction in testis weight, decreased testosterone levels and testicular lesions (WHO/UNEP, 2012, WHO 2012).

Other epidemiological studies describe associations between exposures to single endocrine disruptors and negative health effects. The majority of these studies have focused on associations between single substances and effects. Such associations are in general difficult to establish, and it seems more plausible that effects observed in human populations are induced by the combined exposure to small amounts of a number of different substances from a number of different sources (WHO/UNEP, 2012).

D) Effects in wildlife populations mirror the effects observed in human populations (WHO/UNEP, 2012). For example, in one study, testicular non descent (cryptorchidism) was observed in $68 \%$ of males in a 
population of black deer in Alaska; similar trends were observed in a study of deer in Montana. Other abnormalities were also observed in the black deer in Alaska, such as carcinoma in situ-like cells, which are possible precursors of testicular germ cell cancer and other conditions similar to those observed in men with testicular dysgenesis syndrome. Cryptorchidism has also been reported for horses, pigs, rams, rabbits, cattle, cats and dogs. Also in male polar bears a multitude of reproductive disorders have in recent years been coupled to exposure to chemical substances. (WHO/UNEP, 2012)

As for human epidemiological studies, these studies of wildlife populations are not designed to reveal causalities, and the relative importance of genetic versus environmental factors is difficult or even impossible to assess. However, there are apparent similarities between diseases and disorders reported in humans and in various wildlife populations, which is not surprising given that there is often considerable overlap between the environments and food chains as well as in the physiology of humans and animals (WHO/UNEP, 2012).

\subsection{Widespread occurrence of endocrine disruptors}

Endocrine disruptors with anti-androgenic and oestrogenic properties are considered to be particularly important for effects on the male reproductive system. A vast number of substances, including industrial chemicals, herbicides, fungicides, insecticides and metals are known to affect the synthesis, transport, metabolism and/or action of sex hormones (androgens and oestrogens). Examples of substances, which induce anti-androgenic effects in animal studies are collected in table 1. 


\begin{tabular}{|c|c|}
\hline Substance name & Observed anti-androgenic effects in animal studies \\
\hline DEHP & $\begin{array}{l}\text { In rats: Reduced anogenital distance, increased nipple retention, reduced testicular } \\
\text { weight, histological changes in testis (Danish EPA, 2012). }\end{array}$ \\
\hline DiNP & In rats: Increased nipple retention (Danish EPA, 2012). \\
\hline DBP & In rats: histological changes in testis, changes in mammary glands (Danish EPA, 2012). \\
\hline DiBP & In rats: Reduced anogenital distance, increased nipple retention (Danish EPA, 2012). \\
\hline BBP & In rats: Reduced anogenital distance (Danish EPA, 2012). \\
\hline DPP & $\begin{array}{l}\text { In rats: Reduced anogenital distance, reduced expression of steroidogenic genes in fetal } \\
\text { testes, increased nipple retention (Danish EPA, 2012). }\end{array}$ \\
\hline DnHP & $\begin{array}{l}\text { In rats: Reduced anogenital distance, increased incidences of malformations, increased } \\
\text { nipple retention, delayed sexual maturation, reduced weight of reproductive organs } \\
\text { (Danish EPA, 2012). }\end{array}$ \\
\hline \multirow[t]{2}{*}{$\begin{array}{l}\text { Dioxins and } \\
\text { dioxin-like PCBs }\end{array}$} & $\begin{array}{l}\text { Effects on reproduction, which are in line with an anti-androgenic mode of action, e.g. in } \\
\text { monkeys (Danish EPA, 2012). }\end{array}$ \\
\hline & $\begin{array}{l}\text { Reduced accessory sex organ weights, decreased testis weight, delayed preputial separa- } \\
\text { tion, reduced anogenital distance, delayed testis descent, epididymal malformations, } \\
\text { altered sex behavior, decreased sperm numbers (WHO, 2012). }\end{array}$ \\
\hline PFOA & In rats: Delayed puberty in males and females (Danish EPA, 2012). \\
\hline PFOS & $\begin{array}{l}\text { In mice: Reduced sperm count, reduced testosterone levels, reduced expression of genes } \\
\text { involved in steroidogenesis (Danish EPA, 2012). }\end{array}$ \\
\hline Iprodion & $\begin{array}{l}\text { In rats: Histological changes in testes, prostate, seminal vesicle, epididymis } \\
\text { (Danish EPA, 2012). }\end{array}$ \\
\hline Promycidon & $\begin{array}{l}\text { In rats: Reduced anogenital distance, increased incidence of hypospadias, effects on } \\
\text { testes (Danish EPA, 2012). }\end{array}$ \\
\hline Tebuconazol & In rats: Increased nipple retention (Danish EPA, 2012). \\
\hline DDE & $\begin{array}{l}\text { Increased nipple retention, hypospadias, reduced accessory sex organ weights, reduced } \\
\text { anogenital distance, delayed preputial separation, abnormally small penis, decreased } \\
\text { plasma testosterone levels (WHO, 2012). }\end{array}$ \\
\hline DES & $\begin{array}{l}\text { Decreased testosterone levels, cryptorchidism, reduction in testis weight, testicular } \\
\text { lesions (WHO, 2012). }\end{array}$ \\
\hline Linuron & $\begin{array}{l}\text { Nipple retention, reduced accessory sex organ weights, delayed preputial separation, } \\
\text { decreased testis weight, reduced spermatid number, decreased anogenital distance, } \\
\text { testicular and epididymal malformations (WHO, 2012). }\end{array}$ \\
\hline Lead & $\begin{array}{l}\text { Reduced accessory sex organ weights, decreased testis weight, reduced serum testos- } \\
\text { terone levels, decreased sperm counts (WHO, 2012). }\end{array}$ \\
\hline
\end{tabular}

Many more substances are suspected to be anti-androgenic based on results from in vivo, in vitro or in silico studies, and even more substances are suspected to be able to affect other hormonal pathways, as illustrated in figure 3. There are 194 substances in category 1 (substances with at least 1 in vivo study showing endocrine disruptive effects) on the EU list of suspected endocrine disruptors and nearly 1,000 sub- 
stances on the TEDX (The Endocrine Disruption Exchange, Inc.) list of potential endocrine disruptors (substances with at least one peerreviewed study showing endocrine disruptive effects). However, our current knowledge on endocrine disrupting (e.g. anti-androgenic) properties of substances is limited, since most of the substances in use have never been tested for whether they are endocrine disruptors or not. Using (Q)SAR estimates (Quantitative structure activity relationship), it can be predicted that approximately $10 \%$ of the chemical universe could have anti-androgenic properties. A run of a (Q)SAR model for androgen receptor (AR) antagonism on 37,917 EINECS (European Inventory of Existing Commercial Chemical Substances) substances found that $9.2 \%$ $(3,488)$ were predicted to antagonize the AR, i.e. having anti-androgenic properties (Jensen et al., 2012). It should be taken into consideration that the model focus on substances interacting with the AR, and does not include anti-androgenic substances acting through other mechanisms of action (e.g. inhibition of steroidogenesis), hence increasing the estimated proportion of anti-androgens further.

This is further supported by a recent study showing that at current human exposure levels, the combined exposure of 22 known antiandrogens, did not induce AR antagonistic effects in vitro, thus pointing at human exposure to undiscovered endocrine disruptors to explain the observed declining male reproductive health (Kortenkamp et al. 2014).

\subsection{The importance of regulating endocrine disruptors, including the development of strict scientifically based criteria}

Some of the substances known to induce anti-androgenic or oestrogenic effects in animal studies are already regulated through e.g. a classification for reproductive toxicity (e.g. some phthalates and pesticides). However, as outlined above, our current knowledge on endocrine disrupting properties of substances is limited, since the main part of the substances in use have never been tested for their endocrine disrupting properties.

Due to the time lag between exposure during fetal life and negative health effects in adults, the negative health impacts observed in human populations today were induced 20-40 years ago. Some of the substances used 20-40 years ago have been regulated and substituted by other substances, but humans and wildlife may still be exposed to other substances with similar effects. 
In the scope of REACH, the regulation of plant protection products (PPP) and the Biocidal Product Regulation (BPR), the authorities can request testing for endocrine disrupting properties if a concern is raised by available information, but there is no systematic testing strategy for identification of endocrine disrupting properties of substances within the current EU regulations. Therefore, an improvement in the protection of human health and wildlife can be achieved by 1) development of strict scientifically based criteria for the identification of endocrine disruptors and implementation of these in relevant EU regulation, 2) improvement of the standard information requirements in relevant EU legislation, 3) screening of substances with suspicions of endocrine disrupting properties based on available data, 4) specific testing of suspected endocrine disruptors in order to assess their endocrine disrupting potential, 5) minimized exposure to identified endocrine disruptors. 



\section{The socioeconomic model}

In this chapter we present the assessment framework and model for estimating the cost of illness (COI) developed in this project related to suspected effects of endocrine distruptors on human male reproduction. The selection of three estimates for the etiological fraction (the proportion of negative effects on human male reproductive health attributable to exposure to endocrine disruptors is also described.

\subsection{Overall method}

The aim of this chapter is to present the overall socioeconomic model for estimating the cost of illnesses related to male reproduction suspected to be caused by present annual exposure to endocrine disruptors. First we present the main parts of the model, then the assumptions for each of the main parts, and in the end we include a more detailed description of the assumptions associated with the costs of illness relating to the different diseases.

The approach used in this project is a combination of measurements of costs drawn from public registries in Sweden in relation to health care chains within hospital care that relate to treating the diseases, expert judgement, and estimates from scientific literature. The methods for estimating costs are adapted to the data access in the different fields.

The estimate of cost of illness related to endocrine disruptors is built on three main parts:

- Incidence of illness

The incidence rate of illness is the number of people that fall ill in a disease per year. This is derived from official registries and estimates in scientific reports.

- Estimated incidences due to endocrine disruptors

There are several ways to estimate the incidence rate of an illness that is due to exposure to endocrine disruptors. Our approach is based on estimates of etiological fractions, i.e. estimating the fraction of the total number of incidences of an illness that is related to exposure to endocrine disruptors. 
- Unit cost per incidence

The unit cost per illness is the cost induced per incidence of a disease. These costs are divided into three different types of costs: direct, indirect and intangible costs.

In figure 5 we show our overall model for estimating the costs of effects on human male reproductive health assumed to be associated with exposure to endocrine disruptors.

Figure 5- Overall model of costs and benefits related to endocrine disruptors

Effect

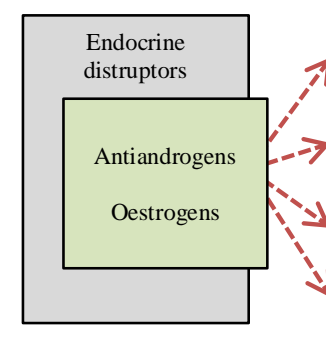

\section{Direct costs Indirect costs}

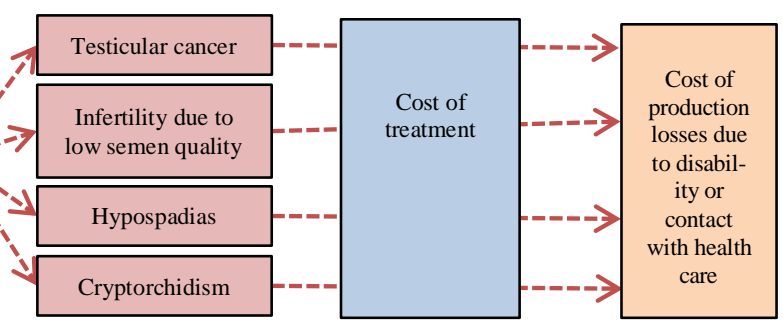

Intangible costs (Suffering and premature death)

Figure comment: the figure describes the causal chains between the increase in risk of diseases, and the health-related costs associated with these diseases. See later sections for more detailed specifications for each of these four diseases.

\subsubsection{Incidence of illness figures applied}

The incidence of the illnesses included in this report differs between countries and regions, and can depend on both genetic and environmental factors. There are no central sources with information about incidence rates. In Table 2 we summarize the data sources for estimates of incidence rates used. The Nordic countries are defined as Denmark, Norway, Sweden, Finland and Iceland. More details regarding the assumptions are presented in the results section of the report. Simple extrapolations of the incidence estimates to EU-28 are included.

Although the incidence of cancer is relatively well covered, this is not the case with the three other conditions covered in this report. Hypospadias for example is an illness that has been associated with stigma and the basis for treatment differs in between countries and regions. As regards testicular cancer, this may be less of a problem since it, unlike hypospadias, is deadly and requires medical attention. 


\begin{tabular}{|c|c|c|c|c|}
\hline Disease & Nordic countries & EU-28 & Comment & References \\
\hline $\begin{array}{l}\text { Testicular } \\
\text { cancer }\end{array}$ & $\begin{array}{r}1,026 \\
\text { cases/year }\end{array}$ & $\begin{array}{r}15,390 \\
\text { cases/year }\end{array}$ & $\begin{array}{l}\text { Nordic estimate: from } \\
\text { database. } \\
\text { Rest of EU estimate: } \\
0.006 \% \text { of male } \\
\text { population in } 2013 \text {. }\end{array}$ & $\begin{array}{l}\text { Nordcan database, Cancer } \\
\text { Research UK 2014, Eurostat } \\
\text { population statistics }\end{array}$ \\
\hline $\begin{array}{l}\text { Infertility due } \\
\text { to low semen } \\
\text { count }\end{array}$ & $\begin{array}{r}5,862 \\
\text { cases/year }\end{array}$ & $\begin{array}{r}103,935 \\
\text { cases/year }\end{array}$ & $\begin{array}{l}4 \% \text { of live male births } \\
\text { per cohort } 2010-2012\end{array}$ & $\begin{array}{l}\text { Svanberg (2003), Nygren and } \\
\text { Lazdane (2006) The National } \\
\text { Board of Health and Welfare } \\
\text { (2011) } \\
\text { Aanesen A. and Gottlieb C. } \\
\text { (2002), Eurostat population } \\
\text { statistics }\end{array}$ \\
\hline Hypospadias & $\begin{array}{r}633 \\
\text { cases/year }\end{array}$ & $\begin{array}{r}11,222 \\
\text { cases/year }\end{array}$ & $\begin{array}{l}0.4 \% \text { of male births } \\
\text { per cohort } 2010-2012\end{array}$ & $\begin{array}{l}\text { EUROCAT database, Swedish } \\
\text { Patient Register, Eurostat } \\
\text { population statistics }\end{array}$ \\
\hline Cryptorchidism & $\begin{array}{r}1,476 \\
\text { cases/year }\end{array}$ & $\begin{array}{r}26,171 \\
\text { cases/year }\end{array}$ & $\begin{array}{l}1 \% \text { of male births per } \\
\text { cohort } 2010-2012\end{array}$ & $\begin{array}{l}\text { Swedish Patient Register, } \\
\text { Eurostat population statistics }\end{array}$ \\
\hline
\end{tabular}

\subsubsection{Assumptions regarding etiological fractions}

One central point in this impact assessment is to estimate the etiological fraction, i.e. the fraction of the total number of incidences (cases/year in this report) of an illness that is assumed to be related to exposure to endocrine disruptors. The better estimate of the etiological fraction, the better the model will be at estimating the associated costs. If we either over or underestimate the etiological fraction this affects the whole cost estimate in a very direct way.

As described in the previous chapter, the strength of the evidence between exposure to endocrine disruptors and negative effects on human male reproductive health (testicular cancer, reduced semen quality, hypospadias and chryptorchidism) seems convincing. However, an exact estimate of the etiological fraction is difficult to assess and will be associated with large uncertainties, since these negative health effects are multifactorial. Some of these "environmental factors" are individual lifestyle related (WHO/UNEP 2012, Sharpe 2010). Examples of other environmental factors which have been linked to the observed effects are dietary factors (de Kort et al., 2011), body mass index and waist circumference (Eisenberg et al., 2014), obesity (Ramlau-Hansen 2007a), smoking (Ramlau-Hansen et al. 2007b and 2007c), degree of physical activity (sedentary life), and alcohol consumption (Sharpe 2010).

Further, it is difficult, based on available epidemiological studies, to prove causal relations between exposure to endocrine disruptors and 
negative health effects, and thus to assess the etiological fraction. The chosen etiological fractions are based on expert advice and on current knowledge about the importance of genetic factors versus various environmental factors.

In the WHO/UNEP report from 2012, it is stated that in general for human diseases and disorders globally, as much as $24 \%$ are estimated to be due to environmental factors:

"It has been estimated that as much as $24 \%$ of human diseases and disorders globally are due at least in part to environmental factors. This provides both a challenge to identify and address, but also a tremendous opportunity to improve human and wildlife health. The recognition of these challenges and opportunities, along with the fact that many of the most prevalent diseases are associated with the endocrine system, has led to a focus on chemical exposures and specifically endocrine disruptors; a subclass of chemicals that act by disrupting the normal functioning of the endocrine system."

WHO/UNEP, 2012

For testicular cancer, it is known that approximately $25 \%$ of the cases have a genetic origin (Ruark et al. 2013, Czene et al., 2002). This leaves $75 \%$ to environmental risk factors. It can be assumed that the same environmental risk factors are at play for the other effects belonging to the testicular dysgenesis syndrome (poor semen quality, cryptorchidism and hypospadias), since they are hypothesized to have a common fetal origin.

As outlined above, the etiological fractions of the environmental factors are not easily assessed, and the effects on male reproductive health are generally thought to have a multifactorial origin.

The etiological fractions used in this report have been chosen in close cooperation with experts within the field of male reproductive health. The levels are 2\% (low), 20\% (medium) and 40\% (high). In figure 6 we illustrate the connection between the level of estimated etiological fraction and incidence of illness.

At the $20 \%$ level we expect that 1,172 cases of infertility is induced due to exposure to endocrine disruptors and 295 cases of chryptorchidism, 205 cases of testicular cancer and 127 cases of hypospadia. 
Figure 6 - Incidences in the Nordic countries at different levels of etiological fractions

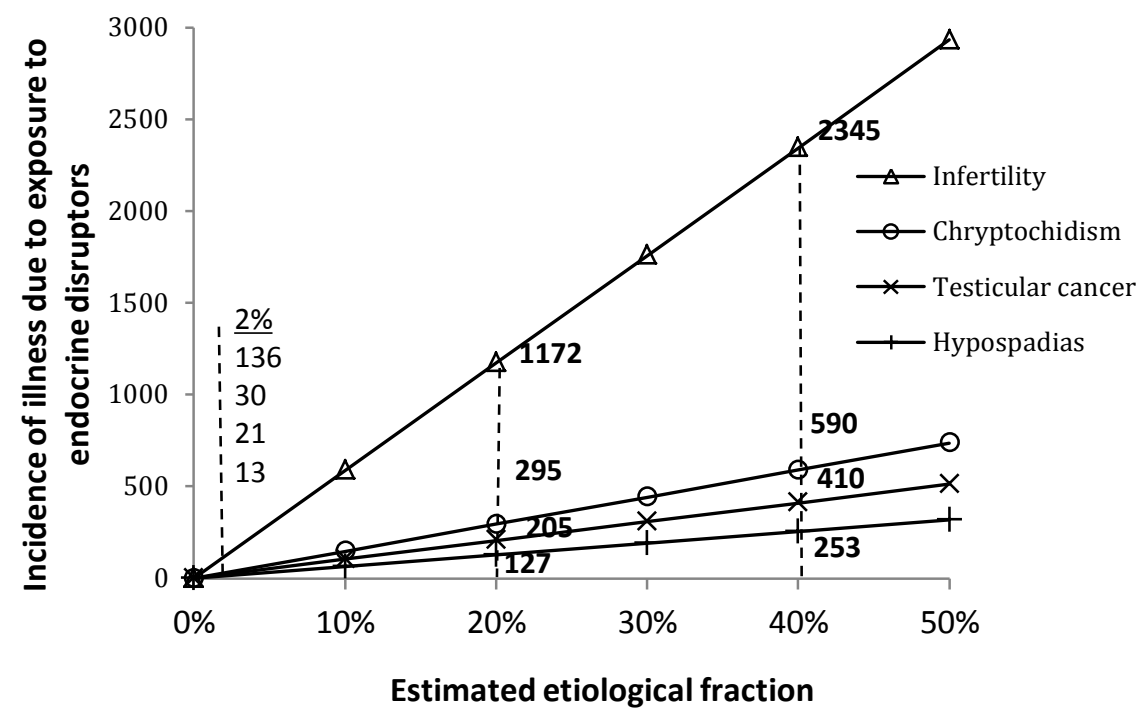

\subsubsection{Cost estimates}

In order to estimate the different costs for each illness we are building cost chains that sum up the costs associated with each illness, defined for the long and short term and when relevant, for different subgroups. The cost chains combine the costs related to the illness, with the costs related to possible secondary effects. Three types of costs have been identified; direct, indirect and intangible costs.

\section{Direct costs}

The direct costs are the costs related to the direct treatment of the illness, in this case mainly costs for hospital health care. All the diseases are to be considered relatively highly specialized areas within healthcare and are mainly treated at hospitals. The cost per incidence data for the different diseases mainly consist of data of number of patients from the National Patient Register ${ }^{3}$ at the Swedish Board of Health and Welfare and details about costs and number of health care contacts from the KPP database 4 at the Swedish Association of Local Authorities and Regions.

\footnotetext{
3 http://www.socialstyrelsen.se/register/hal sodataregister/patientregistret

${ }^{4}$ https://stat.skl.se/kpp/index.htm
} 
The latter make up about $70 \%$ of inpatient health care visits and $55 \%$ of visits to outpatient hospital care. 5

In the case of infertility treatment, the model is different. Since hopital treatment for the testicular cancer, chryptorchidism and hypospadias is free in the Nordic countries, almost all cases will be treated. However, the case is different for infertility treatment which is in general done at the private expense of the patient. Therefore it will be a question of how many treatments that this illness would lead to if all affected men were to be compensated by society. If treated, there will be a direct cost of the treatment of infertility, but if not treated, it will be considered an intangible cost since the illness is not treated and the problem of not being able to conceive still remains. Furthermore, the cost of male infertility can not be estimated through public registries since much of the treatment is done in private clinics. Therefore we estimate the costs by taking into consideration the cost per treatment from different fertility centers and public data from the medical birth registry from the Swedish Board of Health and Welfare.

\section{Indirect costs}

The indirect costs are costs that are induced by illness but not directly related to the treatment for example the production loss due to patients being out of work when receiving treatment. In order to measure indirect costs we created a model for calculation of the production losses. The amount of time lost due to treatment or other sick leave related to illness is estimated through expert interviews (Appendix A). ${ }^{6}$ This involved working out an average treatment scheme for the treatment of each of the different diseases and estimating the associated production losses by combining work hours. The assumed production losses per incidence are described in more detail in Appendix B. This is then valued by the average labor cost per hour (Table 3) and discounted according to which year the effect is supposed to be taking place in relation to the year of incidence of illness.

\footnotetext{
${ }^{5}$ Inpatient care refers to medical care that requires that the patient is admitted to a closed ward. Outpatient care means specialized care in an open hospital ward.

${ }^{6}$ Five interviews were held during february-mars of 2014. After the interviews the experts was contacted with follow up questions mainly regarding estimates of those parts of the model that rely on expert estimates, (ie patient contacts with health care and productivity loss due to contact with health care) and estimates of incidence. For a complete list of experts interviewed, see table A1 in Appendix A.
} 


$\begin{array}{lr}\text { Denmark } & 23.6 \\ \text { Finland } & 23.5 \\ \text { Norway } & 32.2 \\ \text { Sweden } & 21.5 \\ \text { Iceland* } & 23.6 \\ \text { Rest of EU-28** } & 22.2\end{array}$

*Assumed equal to Denmark.

**Average of 15 Member States, weighted by population.

\section{Intangible costs}

Intangible costs relates to the patients life years lost as well as pain and discomfort following from a disease. Intangible costs is the most difficult type of cost to assess in a cost-of-illness-study since a lot of assumptions are necessary and the loss in quality of life incurred following a disease is subjective.

There are a number of methods to evaluate the losses in quality of life and life years due to disease and disability. The most common and accepted measurement is losses in Quality Adjusted Life Years (QALY), which is also the measurement used in this project. QALY is a measurement that combines the two parameters length of life and the quality of life. One QALY corresponds to one year of full health (Bernfort et al. 2012).

In order to make a judgement of the benefits of not having the disease in monetary terms, we will have to make a decision on how much a QALY is worth. Since values and currencies differ between countries there exist a number of different standards of the value of a QALY. ECHA (European Chemicals Agency) states the reference value of an average of EUR 55,800 and a high reference value of EUR 125,200 in the price level of 2003 (ECHA 2008). This is then converted to EUR 70,200 respectively EUR 157,500 in order to match the price levels of $2013.7^{7}$ In this report, the average reference value of EUR 70,200 is used as an estimate of one QALY for testicular cancer, hypospadias and cryptorchidism.

The issue of intangible costs for infertlity is even more complex. In the following chapter we list some methods that can be used to disucss intangible costs of infertility, but we have choosen not to include the values in the final cost estimates.

${ }^{7}$ Using Eurostats HICP index for EU27. 


\subsection{Uncertainties in cost of illness estimates}

The estimates of this model will be associated with different uncertainties. In the end of the results section we elaborate on how uncertainties affects our estimates in order to create a transparent model.

Since our cost of illness (COI) model is really a combined chain of assumptions of effect parameters and cost estimates, the model is only as strong as its parts. In the last part of the results chapter we will discuss the uncertainty of the model estimates of the COI of exposure to endocrine disruptors. The main argument is that we are trying to estimate future costs of diseases based on current treatment schemes. We are also trying to base risks of secondary effects of diseases that are affected by even older treatment since they occur with some delay after the treatment of the primary disease. Improvements in care may mean that the same treatment or the same costs is not necessarily valid for future patients (for assumptions regarding the time schedule of the diseases, see appendix B).

We will discuss uncertainties further in the summary of the model estimates that we present at the end of the report.

\subsection{Discounting}

Future gains and losses are commonly seen as less worth than gains and losses we experience today. Due to this, the timing of the benefits or costs will be of great importance when estimating the present value of the benefits.

The social discount rate is made up of two basic elements: one based on pure time preference (or impatience) and the other based on expected future economic growth. ${ }^{8}$ In the field of environmental and health economics there are standard interest rates that can be used to discount the future benefits of an intervention. These standards can differ somewhat between countries, but most of them are specified around 3-5\%. In this project we used the $4 \%$ level recommended by the European Commission (European Commission 2009). This rate will be used to account for the time lag between exposure and the tangible costs associated with testicular cancer and reduced semen quality. Hypo-

${ }^{8}$ For a more detailed theoretical description and discussion see (e.g.) ECHA (2008). 
spadias and chryptorchidism are assumed to occur shortly (within a year) after substance exposure and are therefore not discounted.

Intangible costs will be treated differently. The QALY losses will only be discounted by the rate of pure time preference. ${ }^{9}$ The reason for this can be explained in two ways - either that society's willingness to pay for QALYs is assumed to grow in line with economic output, thereby compensating the economic growth component of the discount rate; or that human suffering due to illness is unaffected by economic growth. The pure time preference rate is set to $1.5 \%$ (ECHA 2008 \& Scarborough 2010).

${ }^{9}$ In this report we have chosen to discount the number of QALYs lost and then apply a constant value per QALY. An alternative (and perhaps more intuitive) approach is to not discount the number of QALYs lost, but to discount the value per QALY instead. The numerical outcome of the two approaches is identical. 



\section{The Results: Estimating the cost of illness}

In this chapter we present the analysis models for the treatment of the different diseases included in this project and the resulting cost estimates. We do this by presenting care chains developed in collaboration with experts for the different diseases and then presenting the cost estimates for the different diseases. In Figure 5 we presented the overall model that has guided the work with Cost Of Illness (COI)-model. The model is simple, but illustrative of the overall concepts that the analysis contains. From this model we have developed sub-models in order to grasp the whole picture of the cost related to the different diseases included in this project.

\subsection{Testicular cancer}

Testicular cancer is a relatively unusual form of cancer that develops in the testes, usually in males between the ages of 20 to 40 . A patient that is diagnosed with testicular cancer is nowadays mainly treated with surgery first and in some cases also chemotherapy. The clinical costs of testicular cancer are portioned from year one where most of the treatment is done, but regular check ups are done up until ten years after the actual incidence of the disease. Today the mortality of testicular cancer is very low compared with some other forms of cancer but there are still between $2-6 \%$ of the patients in the Nordic countries that have not survived five years after the incidence of the disease.

The yearly incidence in the Nordic countries was 1,026 on average in 2007-2011 (Nordcan). According to Cancer Research UK, the average incidence rate among men in EU is 6.1 per 100,000 (Cancer Research UK 2014). This implies that the incidence in the rest of the EU (i.e. EU-28, excluding the Nordic countries) is around 14,700 per year, and that the annual incidence in EU-28 is approximately 15,390 cases (Table 4).

In figure 7 we show a model of the care chain associated with the average treatment of testicular cancer. 


\begin{tabular}{lr} 
& 2012 \\
Denmark & 286 \\
Finland & 136 \\
Norway & 285 \\
Sweden & 310 \\
Iceland & 9 \\
Nordic & 1,026 \\
EU-28 & 15,390 \\
\hline
\end{tabular}

Figure 7 - Overall cost model for testicular cancer

\section{Treatment of testicular cancer}

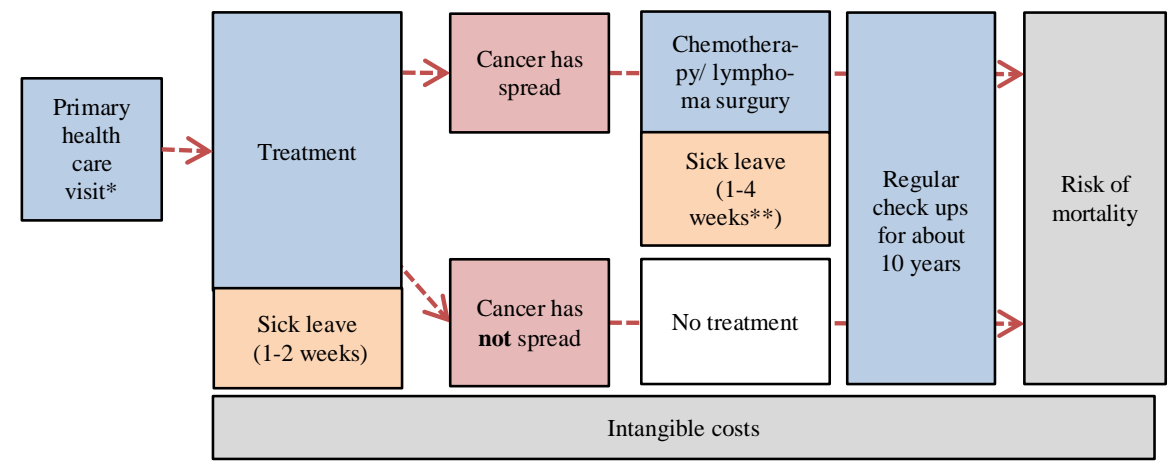

* Primary care is not included in the cost data from the registries and is therefore added to the cost data for hospital care.

** The sick leave depends on the treatment where chemotherapy demands a longer period of treatment (Appendix B).

In the model above we assume that there is an initial cost of 2-3 visits in the primary care when the patient suspects the illness before referral to a specialist. The first step in the treatment is to remove the testicle that is affected by the cancer through an orchidectomy. The testicle is examined and in case the cancer has not spread outside the affected testicle, there is little risk of the cancer reoccuring. If the orchidectomy does not remove the cancer completetly the treatment is usually continued through chemotherapy, but can also be treated with other types of surgury such as surgery of the lymph nodes. The treatment of the disease differs between countries depending on different types of expertise needed and costs associated with different types of treatment.

Every procedure in this chain is associated with an indirect cost of sick leave to attend the medical exams. The first operation is relatively simple and demands only a short period of sick leave. That period is increased further for the patients who undergo chemotherapy. For these patients, we expect a normal sick leave of three weeks per treatment 
(one week inpatient care and two week in between) and corresponding four weeks of sick leave after that. For all cancer patients, the treatment continues with regular check ups for about ten years after the diagnosis (for information about expected treatment schemes, see Appendix B).

Finally, testicular cancer is associated with considerable suffering, both from the treatment (and especially chemotherapy) and from the fact that the illness in som cases is lethal. Therefore also a significant intangible cost is associated with this illness.

\subsubsection{Direct costs}

The direct costs of illness related to testicular cancer are the cost of treatment. In table 5 we present data of patient volume/numbers from the Nordcan database combined with estimates of treatment cost for the different types of treatment taken from the KPP database (KPP, 2014 \& Nordcan, 2014).

\begin{tabular}{|c|c|c|}
\hline & Activities/year & Costs/year* \\
\hline Orchidectomy & 158 & 639 \\
\hline Medical treatment (mainly chemotherapy) & 76 & 484 \\
\hline Lymph node dissection (removal) & 25 & 320 \\
\hline Other & 92 & 427 \\
\hline Testicular cancer as secondary diagnosis** & & 39 \\
\hline Total inpatient care ${ }^{\#}$ & 351 & 1,909 \\
\hline Surgery (including orchidectomy) & 48 & 78 \\
\hline Medical examinations & 302 & 131 \\
\hline Miscellaneous/missing information & 1,824 & 818 \\
\hline Testicular cancer as secondary diagnosis** & & 5 \\
\hline Total outpatient care & 2,174 & 1,031 \\
\hline \multicolumn{3}{|c|}{ Cost estimates based on yearly incidence of 310 (Nordcan, 2014) } \\
\hline \multicolumn{3}{|l|}{ Average costs per incidence (EUR) } \\
\hline Inpatient care ${ }^{\#}$ & & 6,158 \\
\hline Outpatient care $\#$ & & 3,327 \\
\hline Primary health care ${ }^{* * *}$ & & 275 \\
\hline Total cost per incidence & & 9,760 \\
\hline
\end{tabular}

* In thousand EUR. Low estimates from KPP (2014).

** Costs for patients where testicular cancer is listed as a secondary diagnosis in the KPP database (KPP, 2014).

***Assumed 2.5 visits per case (see Appendix B) at SEK 1,000 (EUR 110) each.

\# Inpatient care refers to medical care that requires that the patient is admitted to a closed ward.

Outpatient care means specialized care in an open hospital ward. 
The different treatment scenarios vary with degree of severity and spread of the testicular cancer. However, the big proportion of the costs is spent in outpatient health care. It is unclear what these costs consist of since a big part of the data lacks information about the content of the care. The sum of the direct costs shows that an average incidence of cancer (one patient that falls ill) results in direct health care costs of EUR 9,800. However, in a newly conducted unpublished Danish study the direct cost of one testicular cancer patient amounts to about EUR 33,000 wich is much higher than the estimate done in this project on Swedish data (Almstrup 2014).

In conclusion, the undiscounted direct cost per testicular cancer case is assumed to be approximately EUR 9,800. The average age of incidence is assumed to be 35 years, leading to a discounted value of EUR 2,340 per case. This discounted direct cost estimate is used both for the Nordic countries and for extrapolation to the EU-28.

\subsubsection{Indirect costs}

The indirect costs, such as loss of income, also depend on the sort of treatment that is applied. We have created a model for calculation of the production losses based on several sources and statements and the model has been checked by our expert in testicular cancer (see Appendix B for an illustration of the separate models). Based on our model, on average one case of testicular cancer gives a production loss of 51 work days per cancer case. This is then valued by the average labor cost per hour (Table 3).

The average undiscounted indirect cost per case of of testicular cancer in the Nordic countries is EUR 9,040. The discounted value is EUR 2,170 per case. For EU-28, the discounted average indirect cost is EUR 1,900 per case.

\subsubsection{Intangible costs}

The intangible costs due to testicular cancer are considerable. This is measured by QALY and valued according to ECHAs standard estimation of the value of a lost life year. Stiggelbout et al. (1994) is the only study we have found that estimates QALY for testicular cancer. Stiggelbout et al. uses different methods to estimate the decrease in quality of life which is interesting since it also gives us an idea of the uncertainty of the estimate. Stiggelbout estimates the QALY weights in relation to different treatment schemes, that is whether the patient have received chemotherapy or not, 
and also with different time scopes. The weights for these different schemes range from 0.81-0.93, which is interpreted as a person living on $81-93 \%$ of his potential quality of life compared to if he would not have the disease. However, since this estimate is now twenty years old, it is possible that more modern and effective treatment has increased that level somewhat. Using these weights with data on estimations of life expectancy we get an estimation of average 1.32 QALYs $^{10}$ lost during the affected persons' life time per incidence of testicular cancer.

The mortality rates for testicular cancer are low compared to other types of cancer and the mortality rates have decreased dramatically in the past 50 years. However there are still a fraction of the testicular cancer patients that do not survive. To calculate the average life years lost due to one incidence of testicular cancer we have combined figures of average life expectancy for different age cohorts with the average five year survival rate in the Nordic countries. This means that there are less life years lost if an 80 year old dies than if a 35 year old does the same. The assumption of this calculation is that the disease holds an equal age distribution and that there is an equal mortality rate and life expactancy in all the Nordic countries and the EU. This is an assumption that mainly holds for at least the Nordic countries since the life conditions does not differ greatly in between the Nordic countries. According to this calculation, the average life years lost due to premature death for the incidence of one cancer patient is 0.54. Together with the QALYs lost during the affected individuals' lifetime (see above), the total undiscounted QALY loss per incidence is 1.86 .

Both the estimates of QALYs lost during the affected individuals' life time and years lost due to premature death have been discounted at the rate of $1.5 \%$ representing the level of pure time preference. The period from exposure to occurrence of the incidence - assumed to be 35 years is also discounted by this rate. This leads to a discounted loss of 1.09 QALYs per incidence of testicular cancer. With a value per QALY of EUR 70,210, this corresponds to intangible costs of EUR 76,740. This value is used for the Nordic countries as well as for the EU.

${ }^{10}$ Stiggelbout et al. (1994). This is based on the method called Time Tradeoff. The autors also measures the QALY with the Standard Gamble-method. The value of this corresponds to a discounted QALY loss of 2.8 per incidence of testicular cancer. 


\subsubsection{Summary of testicular cancer costs}

In table 6 we present the key estimates from this section, which will be used in the aggregation of costs expected to occur from exposure to endocrine disruptors.

$\begin{array}{lrr}\begin{array}{l}\text { Table } \mathbf{6} \text { - Summary of estimates regarding costs related to testicular cancer (all cost estimates are } \\ \text { discounted) }\end{array} & \text { Nordic countries } \\ & 1,026 & \text { The EU-28 } \\ & 205 & 15,390 \\ \text { Expected yearly incidence } & & 3,078 \\ \text { of which due to ED substances* } & & \\ \text { Estimated costs per incidence (EUR) } & 2,340 & 2,340 \\ \text { Direct costs } & 2,170 & 1,900 \\ \text { Indirect costs } & 1.09 & 1.09 \\ \text { QALY loss** } & 76,740 & 76,740 \\ \text { Value of QALY loss } & 81,250 & 80,980 \\ \text { Total } & & \\ \text { Costs per year of exposure to ED substances*, million EUR } & 0.480 & 7.198 \\ \text { Direct costs } & 0.444 & 5.843 \\ \text { Indirect costs } & 15.748 & 236.213 \\ \text { Intangible costs } & 16.472 & 249.253 \\ \text { Total } & & \end{array}$

*Based on the medium level assumption of etiological fraction (20\%) used in this report.

** The estimated QALY-loss per case is based on the Total Time Trade-Off (TTO) estimate in Stiggelbout et al. (1994). The same reference make another estimation based on the Standard Gamble (SG) method, which yields 1.98 QALYs lost per incidence (discounted).

\subsection{Infertility due to low semen quality}

This chapter will focus on the costs incurred by individuals due to infertility caused by reduced semen quality. Infertility is defined by the failure to achieve a clinical pregnancy after 12 months or more of regular unprotected sexual intercourse (WHO 2014). We will base our estimate of the cost of infertility due to reduced semen quality on two types of costs; fertility treatment costs (direct cost), and costs on account of loss of working hours (indirect cost).

The cost estimation model applied in this chapter is depicted in figure 8. For every child that would have been concived if not for infertility, the couple will choose one of three paths. The cost per couple is then based on the cost of each path, average number of children, and probability of taking each path. 
Figure 8 - Overall cost model for fertility treatment with ICSI

\section{Fertility treatment model}

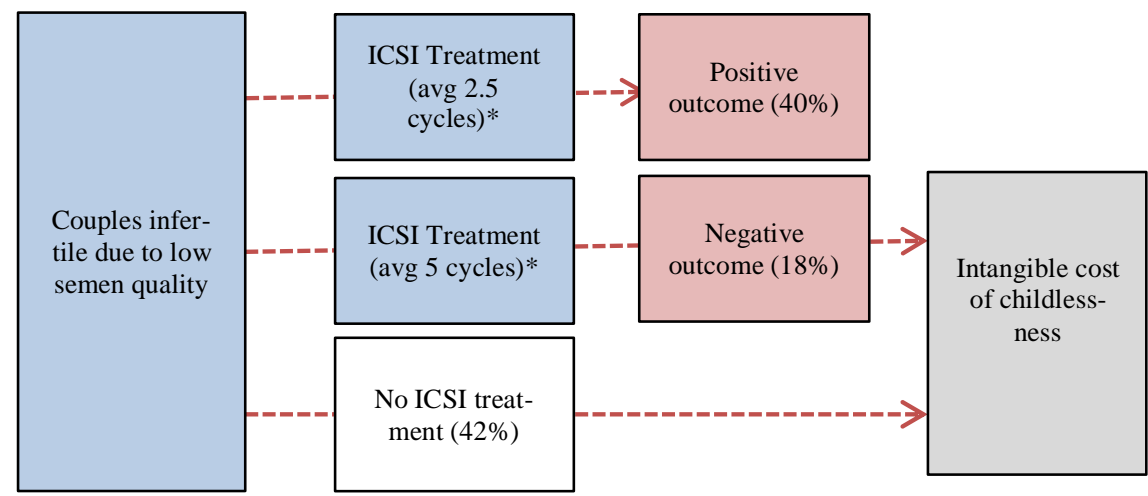

* Productivity loss is estimated at 35.3 days of sick leave per cycle.

In order to estimate the average cost of infertility per individual, due to reduced semen quality a number of assumptions are necessary. First, the incidence needs to be estimated. As described by Mahajan, (2007) estimating the incidence of infertility is a challenge. Control studies suffer from methodological problems and surveys are in many cases biased due to potential stigmatism. The incidence of male infertility due to reduced semen quality applied in this report is $4 \%$ (based on the sources listed in table $\mathrm{C} 1$ in Appendix $\mathrm{C}$ ). The incidence rate will be an important parameter in our estimation of the costs of reduced semen quality; hence, a different incidence rate will alter the estimates.

During 2010-2012 there were around 147,000 male births per year in the Nordic countries (Eurostat 2014). Based on our estimate of incidence, $4 \%$, the number of men born with reduced semen quality resulting in infertility is 5,900 per year in the Nordic countries. Further, based on the latest available data on the fertility ratio for males in Sweden (1.71 (Statistics Sweden, 2014)) we estimate the number of children that will not be born naturally due to reduced semen quality to 10,000 children $(1.71 * 5,900)$. Using the same assumptions (i.e. $4 \%$ and 1.71 ) for the EU as a whole, there are approximately 104,000 men with reduced semen quality per cohort and 178,000 children per year that will not be born naturally due to reduced semen quality.

Based on the number of children, we will set up our model, dividing the children into three different groups: 
1. Children that are born following Intracytoplasmic sperm injection (ICSI) treatment.

2. Children not born following ICSI treatment.

3. Children not born because of other reasons, for example; low WTP, risk aversion, aversion towards treatment etc.

Based on the three groups we have estimated the costs due to reduced semen quality. Of course, one man (and his spouse) can be in two groups. For example; some couples might undergo ICSI treatment with their spouse and receive one child, but choose not to undergo treatment again to get another since the costs are too high. Other men might undergo two treatments with successful result in one and negative result in the other and some might not undergo any treatments at all.

We will estimate the size of each group on 2011 data on fertility treatment and incidence rate per birth year cohort. We are for simplicity and pedagogical reason hence assuming that all treatments for a birth cohort take place the same year.

\subsubsection{Identification of groups}

The fertilization treatment that is considered in this study is Intracytoplasmic sperm injection (ICSI) performed by in vitro fertilisation (IVF). Regular IVF treatment is usually performed when a fertility problem is due to female reproductive problems and is hence not of interest in this project. As of today, ICSI is the only treatment that can, in all but some cases, solve the male part of the infertility diagnosis. In short, ICSI treatment is performed by identifying one healthy sperm (mobility and look) and injecting it directly into an egg in order to fertilize it. The fertilized egg is then transferred to the womans womb. Whether a clinical pregnancy is achieved after the sperm has been injected primarily depends on the womans age but also other charecteristics of the female. ${ }^{11}$

Based on calculations described in Appendix C we estimate the groups, on per child basis, in table 7. The calculations are based on the assumption that couples undergo up to a maximum of five cycles per attempt and that the probability of a successful outcome is constant.

11 Swedish Q-IVF registry and expert opinion Westlander G. 


\begin{tabular}{|c|c|c|c|}
\hline & \multicolumn{2}{|c|}{ ICSI Treatment } & \multirow{2}{*}{$\begin{array}{r}\text { No ICSI Treatment } \\
\text { Group (3) - } \\
\text { No treatment, no outcome }\end{array}$} \\
\hline & $\begin{array}{r}\text { Group (1) - } \\
\text { Successful outcome }\end{array}$ & $\begin{array}{r}\text { Group (2) - } \\
\text { Negative Outcome }\end{array}$ & \\
\hline Proportion in group & $40 \%$ & $18 \%$ & $42 \%$ \\
\hline Average number of cycles & 2.53 & 5 & 0 \\
\hline
\end{tabular}

\subsubsection{Estimation of costs}

The cost estimates derived are estimated "per child" and are based on the three groups that we presented earlier.

The cost per ICSI treatment is estimated to be EUR 2,830 (see Table C.3). Also, couples undergoing ICSI treatment will incur loss of working hours. Based on our expert opinion the loss of working hours is 48 hours ( $24 \mathrm{~h}$ per spouse) if the embryo is fresh and 8 hours ( $4 \mathrm{~h}$ per spouse) if the embryo is frozen. Based on expert judgement and the fraction of the share of treatment that is fresh or frozen, the average loss of working hours per treatment is 35 hours. The weighted average cost per hour is EUR 24.5, for the Nordic countries and EUR 22.2 for the rest of the EU (Table 3). The indirect cost per treatment is EUR 870 in the Nordic countries and EUR 790 for the rest of the EU.

Table 8 summarises the cost per child. The average cost per child is calculated by multiplying the probability of being in each group and the cost of being in each group. As described above, men in Sweden have 1.71 children on average (this is assumed for the other countries as well), hence the total cost per man becomes the average cost per child times the average number of children. The Nordic average cost per child is EUR 7,080 and the average cost per man is EUR 12,100. The average age of incidence is assumed to be 30 years, leading to a discounted tangible cost (direct+indirect) of EUR 3,560 per man. For the rest of the EU, the discounted tangible cost is EUR 3,480 per man. The assumptions related to each of these groups are more thoroughly described in the section below. 


\begin{tabular}{|c|c|c|c|}
\hline & \multicolumn{2}{|c|}{ ICSI Treatment } & \multirow{2}{*}{$\begin{array}{r}\text { No ICSI Treatment } \\
\text { Group (3) - } \\
\text { No treatment, } \\
\text { no outcome }\end{array}$} \\
\hline & $\begin{array}{r}\text { Group (1) - } \\
\text { Successful outcome }\end{array}$ & $\begin{array}{r}\text { Group (2) - } \\
\text { Negative outcome }\end{array}$ & \\
\hline Proportion in group & $40 \%$ & $18 \%$ & $42 \%$ \\
\hline Average number of cycles & 2.53 & 5 & 0 \\
\hline \multicolumn{4}{|l|}{ Costs (EUR) } \\
\hline Direct costs & 7,170 & 14,170 & 0 \\
\hline Indirect costs & 2,190 & 4,330 & 0 \\
\hline Total tangible cost & 9,370 & 18,500 & 0 \\
\hline $\begin{array}{l}\text { Weighted average cost per child } \\
\text { (fraction*cost) }\end{array}$ & 7,080 & & \\
\hline Weighted average cost per man & 12,100 & & \\
\hline
\end{tabular}

- Group (1), children born through ICSI treatment, first of all incur the medical costs of ICSI treatment calculated to EUR 7,170 (2.53* EUR 2,830). The cost of production lost for those who are successful thus is $2.53 *$ EUR $870=$ EUR 2,190.

- Group (2), children not born following ICSI treatment, is the most costly event. The cost of five ICSI treatments (EUR 2,830*5 $=$ EUR 14,170$)$ and the associated production loss $(5 * 870=$ EUR 4,330 ) is incurred on the couple. These couples will also suffer intangible costs due to involuntary childlessness.

- Group (3), children not born through ICSI treatment, will consist of couples that potentially do not want to undergo treatment to get another child, do not want to undergo treatment at all, do not have the financial means to undergo treatment and/or are too risk averse to undergo treatment. This group will not incur any direct or indirect costs. A part of the group are however likely to suffer intangible costs due to involuntary childlessness.

\subsubsection{Intangible costs of involuntary childlessness}

According to the analysis above there are approximately 2,000-7,00012 wanted but unborn children in the Nordic countries every year. Quantifying the intangible costs incurred on couples who are not able to con-

12 The lower bound comprising group 2, while the higher bound includes group 3 as well. 
ceive a child is problematic. The main reason for this is that there is no relevant estimate to be found of the value of conceiving a child.

There are a range of possible approaches to estimate the cost of involuntary childlessness. These approaches include:

- willingness to pay for adoption

- willingness to pay for IVF treatment, above the direct costs (see e.g. Spiegel et al. 2013 \& Granberg 1995)

- estimating the economic contribution that the unborn child would make during its lifetime (if born)

- contingent valuation.

Neither of these methods have however been developed to an extent to which it is possible to get a comprehensive estimation of these types of costs. Therefore they will not be considered further in this report. It is however important to keep in mind that these costs are potentially substantial.

\section{Summary of infertility costs}

In table 9 we present the key estimates from this section, which will be used in the aggregation of costs expected to occur from exposure to endocrine disrupting substances.

\begin{tabular}{|c|c|c|}
\hline & Nordic countries & EU-28 \\
\hline Expected yearly incidence & 5,862 & 103,935 \\
\hline of which due to ED substances* & 1,172 & 20,787 \\
\hline \multicolumn{3}{|c|}{ Estimated costs per incidence (EUR) } \\
\hline Direct costs & 2,720 & 2,720 \\
\hline Indirect costs & 830 & 760 \\
\hline Total** & 3,560 & 3,480 \\
\hline \multicolumn{3}{|c|}{ Costs per year of exposure to ED substances*, million EUR } \\
\hline Direct costs & 3.194 & 56.630 \\
\hline Indirect costs & 0.978 & 15.698 \\
\hline Total** & 4.171 & 72.328 \\
\hline
\end{tabular}

*Based on the medium level assumption of etiological fraction (20\%) used in this report.

**The totals do not include any intangible costs related to infertility.

In addition to these tangible costs, there are intangible costs of male infertility that have not been quantified in this report. 


\subsection{Hypospadias}

Hypospadias is a birth defect of the urethra in males manifested by an abnormally placed urinary opening. A baby that is born with hypospadia has its external urinary opening anywhere alongside a line running from the tip of the penis to the junction between the penis and the scrotum. Depending on the degree of hypospadia (how close to the junction of the penis and scrotum the opening of the urinary opening is), treatment is surgical repair which can be more or less extensive depending on the degree of impairment. Costs associated with hypospadias are mainly medical costs but there are also some potential costs for the parents sick leave in relation to the surgery on their children who suffers from the illness. We have also identified two diseases that are higher in prevalence among hypospadias patients. It is estimated that $15 \%$ of hypospadias patients later is treated for urethrocutaneous fistula and 10\% for uretra stricture, as a secondary effect of their hypospadial condition.

Incidence and prevalence of hypospadias (as well as cryptorchidism) is hard to estimate since there is a tendency to diagnose the illness in different ways in different countries or even at different hospitals in the same country. The reported incidence differs significantly between countries and studies. Toppari et al. (2001) presented a collection of estimates of hypospadias from different countries. These estimates ranged between $1.4-1.8 \%$ of all boys in the Nordic countries except for Finland where the incidence was found to be $0.5 \%$. The estimates differ greatly between sources. Lund et al. (2009) estimated the prevalence to be $0.52 \%$ in 2006 based on a Danish registry study, which is much lower than other estimations. We will use estimates of number of cases from the Swedish Patients Registry (Patientregistret, 2014) and the EUROCAT database (2014) on prevalence of illness, which is more in line with the estimation from Lund et al. than from Toppari et al. These estimates are presented below, along with the number of male births per year and the resulting estimated annual incidence.

In figure 9 we show our theoretical model of the procedure of treatment of hypospadias. 
Table 10 - Incidence of hypospadias in the Nordic countries

\begin{tabular}{lrrr} 
& $\begin{array}{r}\text { Expected incidence per live male birth } \\
\text { (EUROCAT \& Swedish Patients Registry) }\end{array}$ & $\begin{array}{r}\text { Male births per year, } \\
\mathbf{2 0 1 0 - 2 0 1 2} \text { (Eurostat } \\
\text { population statistics) }\end{array}$ & $\begin{array}{r}\text { Expected incidences } \\
\text { per year }\end{array}$ \\
Denmark & $0.32 \%$ & 29,500 & 94 \\
Finland & $0.38 \%$ & 29,500 & 112 \\
Norway & $0.45 \%$ & 29,700 & 134 \\
Sweden & $0.51 \%$ & 55,600 & 284 \\
Iceland* & $0.43 \%$ & 2,280 & 10 \\
Rest of EU-28* & $0.43 \%$ & $2,480,000$ & 10,733 \\
& & & 633 \\
Nordic & & & 11,222 \\
EU-28 & & & 6 \\
\hline
\end{tabular}

*The incidence rates for Iceland and the rest of the EU are assumed to be equal to the weighted average of the four other countries.

Figure 9 - Treatment and secondary effects of hypospadias

$\underline{\text { Hypospadias }} \quad \underline{\text { Secondary effects }}$

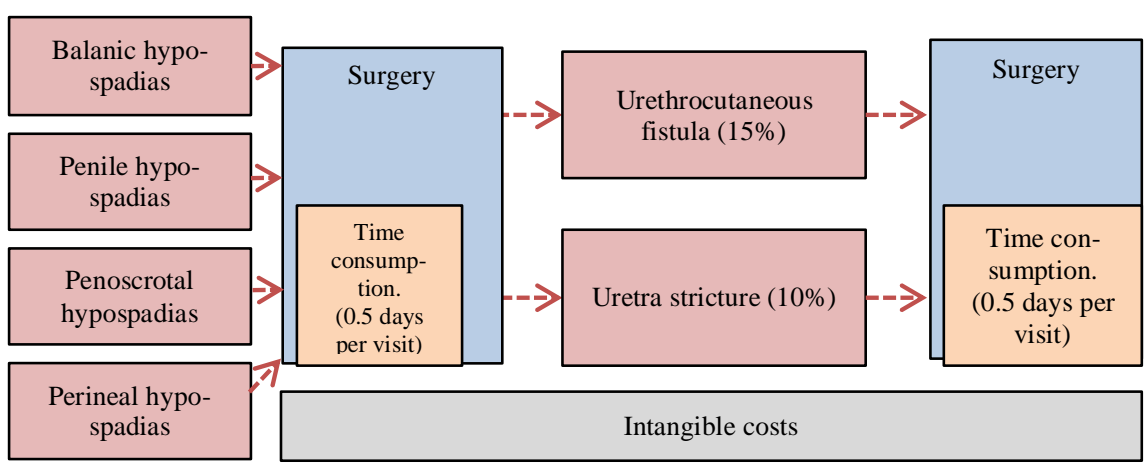

Comment: For more detailed information on how we have calculated production losses due to illness go to Appendix B.

\subsubsection{Costs of hypospadias}

Direct costs of hypospadias are relatively uncomplicated. Hypospadias can have different degrees of severity from balanic hypospadias (the urinal opening is slightly below normal) to perineal hypospadias (the urinal opening is below the scrotum). We will not distinguish between costs of the different severities since we expect that the treatment procedure is roughly the same (however there are some adjustments according to severity in the model for indirect costs).

The treatment of hypospadias is done through a single plastic surgery of the penis. Except for the direct treatment we also include the most relevant indirect costs related to hypospadias. 
In table 11 we present estimates of the direct cost associated with the treatment of hypospadias in Sweden 2012.

\begin{tabular}{|c|c|c|}
\hline & Activities/year & Costs/year* \\
\hline Surgery for hypospadias & 243 & 1,251 \\
\hline Miscellaneous/missing information** & 113 & 387 \\
\hline Hypospadias as secondary diagnosis*** & & 52 \\
\hline Total inpatient care\# & 356 & 1,690 \\
\hline Surgery for hypospadias & 184 & 292 \\
\hline Miscellaneous/missing information** & 2,244 & 681 \\
\hline Hypospadias as secondary diagnosis*** & & 4 \\
\hline Total outpatient care\# & 2,428 & 976 \\
\hline \multicolumn{3}{|c|}{ Cost estimates based on yearly incidence of 284 (EUROCAT, 2014) } \\
\hline \multicolumn{3}{|l|}{ Average cost per incidence (EUR) } \\
\hline Inpatient care\# & & 6,014 \\
\hline Outpatient care\# & & 3,475 \\
\hline Secondary effects $* * * *$ & & 809 \\
\hline Total cost per incidence & & 10,297 \\
\hline
\end{tabular}

*In thousand EUR. "Low” estimates from KPP (2014).

**Activity not specified in KPP (2014).

***Costs for patients where hypospadias is listed as a secondary diagnosis in KPP (2014).

**** The costs for secondary effects are based on an expert judgement (see Appendices A \& B) that $15 \%$ of hypospadias patients later is treated for Urethrocutaneous fistula and that $10 \%$ are treated for Uretra stricture, as a later effect of their hypospadias condition. The cost per case of $U$. fistula is estimated to be EUR 3,900 and the cost per case of U. stricture is estimated to be EUR 2,300 (KPP 2014). \# Inpatient care refers to medical care that requires that the patient is admitted to a closed ward. Outpatient care means specialized care in an open hospital ward.

As stated in table 11 the average direct cost related to the treatment of hypospadias is estimated to EUR 10,300 per patient, which is the estimate used for all countries in this report. Since the occurrence of hypospadias is assumed to be within a year of exposure, this estimate is not discounted. In the same unpublished Danish study mentioned previously in the testicular cancer section (Almstrup 2014), the direct cost of one hypospadias patient amounts to about EUR 6,800 which is somewhat lower than the estimate we get from the Swedish registry.

Relevant indirect costs of hypospadias are quite simple. They are the production losses related to the illness for the parents that are away from work taking care of the child in relation to the surgery. A simple estimate is that on average 3-5 work days are lost due to parents not working during the treatment and in total one more day of sick leave to attend 2-4 checkups (depending on severity) and also a few more days in the case of later complications. This is based on expert judgement (see Appendices A \& B). The average volume of sick days related to the incidence of one hypospadias case is estimated to an average of 7.8 sick days 
per incidence of hypospadia, which (with the labor cost estimates in Table 3) implies indirect costs of EUR 1,400 in the Nordic countries and EUR 1,200 in the rest of the EU.

\subsubsection{Intangibles}

The intangible costs of hypospadias depend on the severity of the state of illness and how successful surgery is. However with successful surgery the psychosexual impairment should be small. In an health economic evaluation of anti-epilieptic drug therapies Jentik et al. (2012) uses an estimate of QALY-equivalent life years lost of hypospadias corresponding to on average 0.8 life years lost per case of hypospadias (discount$\mathrm{ed}^{13}$ value of 0.40 ). This estimate may seem quite high. However, on one hand, hypospadias is a chronic illness that corrected or not in some way may follow you through your whole life. That means that even a small impairment of your quality of life may aggregate to a big loss in aggregate quality of life. On the other hand, in the light of a meta study of controlled studies of quality of life estimates of hypospadias carried through by Schönbucher et al. (2008), there is little or no evidence of psychosexual impairment of boys with hypospadias, which means that a successful hypospadias surgery leads to a small loss of quality of life. Thus, since there has been improvement in treatment tecniques on hypospadias there is some uncertainity related to the use of older QALY measurements. However we use the discounted 0.40 level stated above, but the estimate should probably be considered a high estimate. Taking into account the value per QALY used in this report, the intangible costs amounts to EUR 28,080/case (0.40 QALY/case * EUR 70,200/QALY).

\footnotetext{
${ }^{13}$ Since information was missiong on method for estimation in Jentik et al. we build a discounting model assuming that the QALYs lost were distributed evenly for 80 years and discounted with the pure time preference rate of $1.5 \%$ used thoughout this report.
} 


\subsubsection{Summary of hypospadias costs}

In table 12 we present the key estimates from this section, which will be used in the aggregation of costs expected to occur from exposure to endocrine disrupting substances.

\begin{tabular}{|c|c|c|}
\hline & Nordic countries & EU-28 \\
\hline Expected yearly incidence & 633 & 11,222 \\
\hline of which due to ED substances* & 127 & 2,244 \\
\hline \multicolumn{3}{|c|}{ Estimated costs per incidence (EUR) } \\
\hline Direct costs & 10,297 & 10,297 \\
\hline Indirect costs & 1,368 & 1,243 \\
\hline QALY loss & 0.40 & 0.40 \\
\hline Value of QALY loss & 28,077 & 28,077 \\
\hline Total & 39,742 & 39,616 \\
\hline \multicolumn{3}{|c|}{ Costs per year of exposure to ED substances*, million EUR } \\
\hline Direct costs & 1.304 & 23.111 \\
\hline Indirect costs & 0.173 & 2.789 \\
\hline Intangible costs & 3.556 & 63.017 \\
\hline Total & 5.033 & 88.917 \\
\hline
\end{tabular}

*Based on the medium level assumption of etiological fraction (20\%) used in this report.

\subsection{Cryptorchidism}

Cryptorchidism is a birth defect where one or two testes have not decended into the scrotum at birth but remain in the abdomen. Normally this illness is congenital, but it can also develop later in life. Later development of cryptorchidism is rare and according to our expert also not relevant for this study since it depends on other factors than hormones. For newborns, the primary line of action is to wait for self-resolution. If it does not resolute naturally, a surgery called orchiopexy is performed ideally in the first life year of the child.

As we concluded in the previous chapter, the incidence rate of cryptorchidism is quite hard to estimate and it depends on the definition of the illness. First, a large proportion of chryptorchidism cases resolve themselves without health care actions. Second, there are also some cases of the illness occurring later in life and not at birth. We strive to include only inborn cases since our expert assumtion is that these are the cases that could be connected with exposure to endocrine disruptors. Finally, we include only the cases that are treated for chryptorchidism. In order to estimate the incidence level in the Nordic countries we use an incidence rate of $1 \%$ (560 cases out of 55,600 male births in 2012) from the Swedish patient registry and assume equal incidence 
rates for the other Nordic countries and the rest of the EU (Table 13). The main reason for this is that we only want to count the number of cases that require treatment, since these are the cases that induce costs. Other incidence studies often focus on the total incidence of chryptorchidism of which only about one fifth requires medical treatment. ${ }^{14}$

Table 13 - Incidence of chryptorchidism

$\begin{array}{lrr} & \begin{array}{r}\text { Male births per year, 2010-2012 } \\ \text { (Eurostat population statistics) }\end{array} & \begin{array}{c}\text { Expected incidences per year } \\ \text { Denmark }\end{array} \\ \text { Finland } & 29,500 & 297 \\ \text { Norway } & 29,500 & 297 \\ \text { Sweden } & 29,700 & 299 \\ \text { Iceland } & 55,600 & 560 \\ \text { Rest of EU-28 } & 2,280 & 23 \\ \text { Nordic } & 2,480,000 & 25,017 \\ \text { EU-28 } & & 1,476 \\ \end{array}$

\subsubsection{Direct costs}

In table 14 we present estimates of the direct cost associated with the treatment of chryptorchidism in Sweden 2012 (KPP, 2014 \& Patientregistret, 2014).

In table 14 we see that the direct costs of treatment of cryptorchidism in Sweden is estimated at about EUR 4,400 per patient, which is the estimate used for all countries in this report. Since the occurrence and treatment of chryptorchidism is assumed to be within a year of exposure, this estimate is not discounted.

In the unpublished Danish study mentioned previously, the direct cost of cryptorchidism was estimated at EUR 3,200 per patient, which is somewhat lower than our estimate (Almstrup 2014).

Like in the case of hypospadias, the indirect costs related to Cryptorchidism are mainly the volume of the parents' sick leave. This estimate is based on information from our expert and is estimated to an average of 0.5 day of production loss per visit and 2-3 days for the surgery. In total we estimate the production loss to 6 work days per incidence, which (with the labor cost estimates in Table 3) implies indirect costs of EUR 1,200 in the Nordic countries and EUR 1,000 in the rest of EU.

\footnotetext{
${ }^{14}$ Estimated incidence in the Nordic and EU countries are presented in chapter 2 on the socioeconomic model (Table 2).
} 
Table 14 - Summary of direct costs of treatment of cryptorchidism in Sweden

\begin{tabular}{|c|c|c|}
\hline & Activities/year & Costs/year* \\
\hline Surgery for chryptorchidism & 135 & 527 \\
\hline Miscellaneous/missing information** & 76 & 237 \\
\hline Cryptorchidism as secondary diagnosis*** & & 49 \\
\hline Total inpatient care\# & 211 & 814 \\
\hline Surgery for cryptorchidism & 433 & 742 \\
\hline Miscellaneous/missing information** & 1,984 & 921 \\
\hline Cryptorchidism as secondary diagnosis*** & & 4 \\
\hline Total outpatient care\# & 2,417 & 1,666 \\
\hline \multicolumn{3}{|c|}{ Cost estimates based on a yearly incidence of 560 (Patientregistret, 2014) } \\
\hline \multicolumn{3}{|l|}{ Average cost per incidence (EUR) } \\
\hline Inpatient care\# & & 1,453 \\
\hline Outpatient care\# & & 2,976 \\
\hline Total cost per incence & & 4,429 \\
\hline
\end{tabular}

* In thousand EUR. "Low" estiamtes from KPP (2014).

**Activity not specified in KPP (2014).

***Costs for patients where hypospadias is listed as a secondary diagnosis in KPP (2014).

\# Inpatient care refers to medical care that requires that the patient is admitted to a closed ward.

Outpatient care means specialized care in an open hospital ward.

Successful surgery of chryptorchidism means that there is little risk of having more complications later in life and today almost all boys who are chryptorchide are also operated in the countries that we study. Van den Akker et al. (2013) estimated the loss of QALY per incidence of cryptorchidism to an average 0.8415 (corresponding to 0.42 discounted at a pure time preference rate of $1.5 \%$ ). We use the discounted value in our further analysis. With a value per QALY of EUR 70,200, the indirect costs are EUR 29,200 per case.

\subsubsection{Summary of chryptorchidism costs}

In table 15 we present the key estimates from this section, which will be used in the aggregation of costs expected to occur from exposure to endocrine disruptors.

\footnotetext{
15 This estimate is based on van den Akkers estimate. However van den Akker et al. (2013) used a discount rate of $3 \%$ which had to be recalculated to the $1.5 \%$ rate we use in this resport. Van den Akker et al. presents a discounted estimate of 0.21 per incidence, which adjusted by the interest rate we use corresponds to 0.42 QALYs lost per incidence.
} 
Table 15 - Summary of estimates regarding costs related to chryptorchidism (all cost estimates are discounted)

\begin{tabular}{lrr} 
& Nordic countries & EU-28 \\
\hline $\begin{array}{lr}\text { Expected yearly incidence } \\
\text { of which due to ED substances* }\end{array}$ & 26,171 \\
Estimated costs per incidence (EUR) & 1,476 & 5,234 \\
Direct costs & 295 & 4,429 \\
Indirect costs & 4,429 & 1,045 \\
QALY loss & 1,154 & 0.42 \\
Value of QALY loss & 0.42 & 29,200 \\
Total & 29,200 & 34,673 \\
Costs per year of exposure to ED substances*, million EUR & 34,782 & 23.180 \\
Direct costs & & 5.470 \\
Indirect costs & 1.307 & 152.836 \\
Intangible costs & 0.341 & 181.485 \\
Total & 8.620 & 10.267 \\
\hline
\end{tabular}

*Based on the medium level assumption of etiological fraction (20\%) used in this report.

\subsection{Estimating the costs in the Nordic countries}

In this last part of the report we summarize the different parts of our analysis and combine the estimates of costs and incidences with estimations of etiological fractions presented in the previous chapter. In table 16 we summarize the results related to different diseases that are within the scope of our project. In table 16, we use an etiological fraction of $20 \%$ as the central estimate. However, this level is used only to illustrate the costs at a chosen estimate since we don't have exact information of which is the real etiological fraction, which could be $2 \%$ as well as $40 \%$. Estimated costs per Nordic country are presented in Appendix D.

The discounted costs per year of exposure to endocrine disruptors related to human male reproduction are estimated to be approximately EUR 36 million in the Nordic countries, when assuming an etiological fraction of $20 \%$ (Table 16). This estimation does not include the intangible costs of infertility, which may be substantial. The total direct costs of treatment are estimated at EUR 6.3 million per year, and the annual indirect costs of production loss are estimated to EUR 1.9 million. The annual loss of quality adjusted life years (QALYs) is approximately 398, implying intangible costs (excluding the costs of infertility) of EUR 28 million. This indicates that the intangible costs related to reduced life quality and lost life years is the major source of socioeconomic costs of the illnesses analysed in this report. 
Table 16-Summary of estimated discounted costs of illness on human male reproduction in the Nordic countries due to exposure to endocrine disruptors, assuming an etiological fraction of $20 \%$ (million EUR/year of exposure)

\begin{tabular}{lrrrr} 
& Testicular cancer & Infertility & Hypospadias & Chryptorchidism \\
Tangible costs & 0.924 & 4.171 & 1.477 & 1.648 \\
- of which Direct & 0.480 & 3.194 & 1.304 & 1.307 \\
- of which Indirect & 0.444 & 0.978 & 0.173 & 0.341 \\
Intangible costs & 15.748 & $*$ & 3.556 & 8.620 \\
- Based on number of QALYs lost & 224 & - & 51 & 123 \\
Total costs & 16.672 & $4.171^{*}$ & 5.033 & 10.267 \\
\hline
\end{tabular}

*The intangible costs of male infertility due to reduced semen quality are not quantified in this report. These costs may however be substantial.

Of the illnesses analysed, testicular cancer is the one that generates the highest socio-economic cost (Figure 10), even though the incidence of the cancer cases are expected to occur 30 years into the future and the costs have been discounted to take account of this. A lower discount rate would make the dominance of testicular cancer (in the total costs) even stronger. It is, however, important to note that the costs for infertility are not directly comparable with the costs for the other illnesses, since intangible costs of infertility are not quantified in this report.

Figure 10 - Cost of effects on human male reproduction in the Nordic countries due to endocrine disruptors at different levels of assumed etiological fractions (millions of Euro per year of exposure)

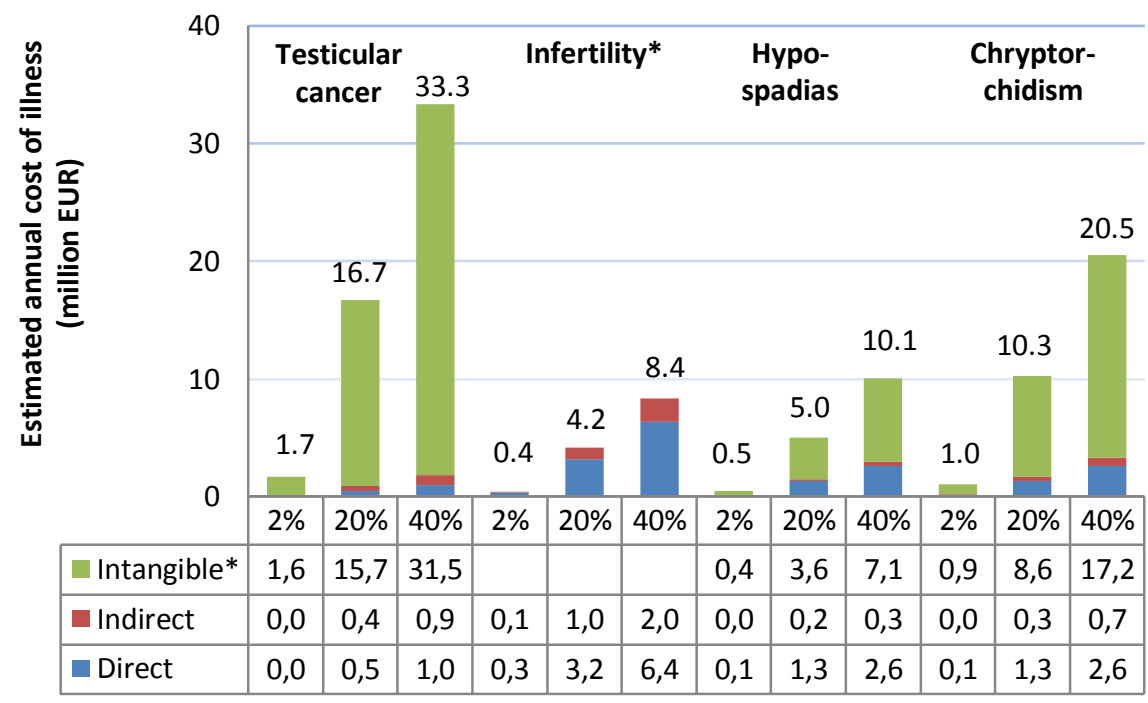

*Intangible costs of infertility are not quantified in this report. 
Assuming another etiological fraction than $20 \%$ will change the results above proportionally. An etiological fraction of $2 \%$ yields a total cost of EUR 3.6 million per year of exposure while an etiological fraction of $40 \%$ implies costs of EUR 72 million per year of exposure (Figure 10).

\subsection{Estimating the costs in the EU-28}

While estimating the socio-economic costs for the Nordic countries we have also made some simple extrapolations to estimate the equivalent costs in the EU.

The incidence estimation for testicular cancer in the EU is based on EU wide data, while the incidences for the other adverse health effects studied are based on Swedish or Nordic incidence rates that have been applied to data on live male births per year in the EU. The direct costs per case are assumed to be equal to those in Sweden. This is likely to be an overestimation of the acutal average costs in the EU. The indirect costs are derived by applying the same productivity loss estimates as in the Nordic countries (based on expert judgement, see Appendix B), and an estimate of average labor costs in the EU. The QALY loss per incidence is assumed equal across the EU, and the value per QALY used is an EU default value provided by ECHA (2008). For more details on the extrapolation, see the result section for each illness respectively.

Assuming an etiological fraction of $20 \%$ implies discounted socioeconomic costs per year of exposure to endocrine disruptors of EUR 592 million in the EU-28 (Table 17). Assuming another etiological fraction than $20 \%$ will change the results proportionally. An etiological fraction of $2 \%$ yields a total cost in the EU-28 of EUR 59 million per year of exposure while an etiological fraction of $40 \%$ implies costs of nearly 1,200 million per year of exposure (Figure 11).

\begin{tabular}{|c|c|c|c|c|}
\hline & Testicular cancer & Infertility & Hypospadias & Chryptorchidism \\
\hline Tangible costs & 13.0 & 72.3 & 25.9 & 28.7 \\
\hline - of which Direct & 7.2 & 56.6 & 23.1 & 23.2 \\
\hline - of which Indirect & 5.8 & 15.7 & 2.8 & 5.5 \\
\hline Intangible costs & 236.2 & $*$ & 63.0 & 152.8 \\
\hline - Based on number of QALYs lost & 3,364 & - & 898 & 2,177 \\
\hline Total costs & 249.3 & $72.3^{*}$ & 88.9 & 181.5 \\
\hline
\end{tabular}

*The intangible costs of male infertility due to reduced semen quality are not quantified in this report. These costs may however be substantial. 
As illustrated in Figure 11, the pattern is similar to the one found in the Nordic countries, the intangible costs are high, and the direct costs of health care are lower. According to this simple extrapolation, for each year of exposure to endocrine disruptors, the countries of the EU have tangible costs of approximately EUR 140 million for treatment of negative effects on male reproductive health, assuming an etiological fraction of $20 \%$. As for the Nordic countries, the big costs are the intangible costs that add up to approximately EUR 452 milions per year of exposure given an etiological fraction of $20 \%$. Finally, the indirect costs in the EU are estimated to approximately EUR 30 milions per year of exposure given the same etiological fraction.

Figure 11-Cost of effects on human male reproduction in the EU-28 due to endocrine disruptors at different levels of assumed etiological fractions (millions of Euro per year of exposure)

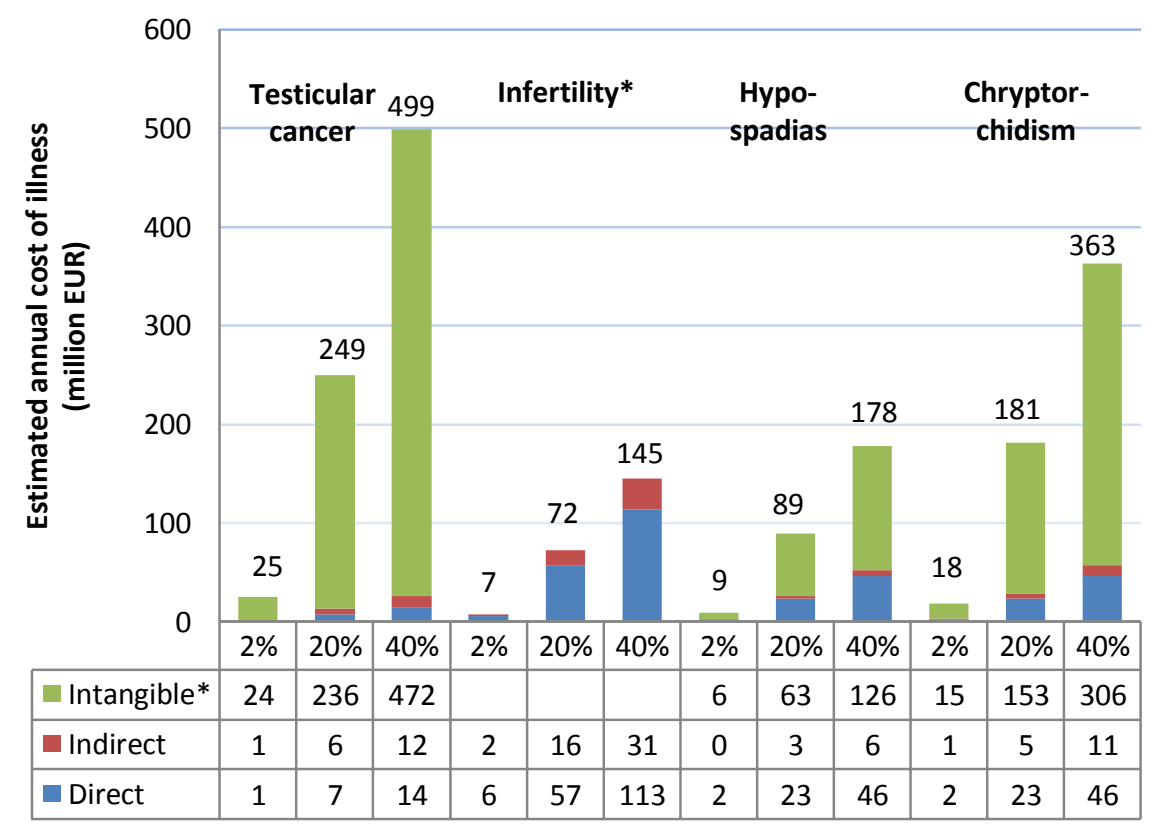

*The intangible costs of infertility are not quantified in this report.

There are not many studies assessing the costs related to exposure to endocrine disruptors, but recently a report was published by the nongovernmental organisation (NGO), Health and Environment Alliance (HEAL) (HEAL, 2014). In table 18, the estimates in the HEAL report are compared with the estimates from this report. 


\begin{tabular}{|c|c|c|}
\hline & HEAL 2014 & This report (EU-28) \\
\hline Human infertility & $\begin{array}{l}\text { Etiological fraction } 2 \% \text { : } \\
\text { EUR } 48-61 \text { million/year } \\
\text { Etiological fraction } 5 \% \text { : } \\
\text { EUR } 120-155 \text { million /year } \\
\text { All assisted reproduction. Direct costs } \\
\text { included }\end{array}$ & $\begin{array}{l}\text { Etiological fraction } 2 \% \text { : } \\
\text { EUR } 7 \text { million /year } \\
\text { Etiological fraction } 20 \% \text { : } \\
\text { EUR } 72 \text { million /year } \\
\text { Only assisted reproduction related to } \\
\text { male infertility. Direct and indirect } \\
\text { costs included. }\end{array}$ \\
\hline Cryptorchidism & $\begin{array}{l}\text { Etiological fraction } 2 \% \text { : } \\
\text { EUR } 18-26 \text { million /year } \\
\text { Etiological fraction } 5 \% \text { : } \\
\text { EUR } 45-65 \text { million /year } \\
3 \% \text { incidence rate. Direct costs } \\
\text { included. }\end{array}$ & $\begin{array}{l}\text { Etiological fraction } 2 \% \text { : } \\
\text { EUR } 18 \text { million /year } \\
\text { Etiological fraction } 20 \% \text { : } \\
\text { EUR } 181 \text { million /year } \\
1 \% \text { incidence rate. Direct, indirect and } \\
\text { intangible costs included }\end{array}$ \\
\hline Hypospadias & $\begin{array}{l}\text { Included in the headline for cryptor- } \\
\text { chidism, but seems not to be included } \\
\text { in calculations. }\end{array}$ & $\begin{array}{l}\text { Etiological fraction } 2 \% \text { : } \\
\text { EUR } 9 \text { million /year } \\
\text { Etiological fraction } 20 \% \text { : } \\
\text { EUR } 89 \text { million /year }\end{array}$ \\
\hline Testidular cancer & Not included & $\begin{array}{l}\text { Etiological fraction } 2 \% \text { : } \\
\text { EUR } 25 \text { million /year } \\
\text { Etiological fraction } 20 \% \text { : } \\
\text { EUR } 249 \text { million /year }\end{array}$ \\
\hline Total & $\begin{array}{l}\text { Etiological fraction } 2 \% \text { : } \\
\text { EUR } 66-87 \text { million /year } \\
\text { Etiological fraction } 5 \% \text { : } \\
\text { EUR } 165-220 \text { million /year }\end{array}$ & $\begin{array}{l}\text { Etiological fraction } 2 \% \text { : } \\
\text { EUR } 59 \text { million /year } \\
\text { Etiological fraction } 20 \% \text { : } \\
\text { EUR } 592 \text { million /year }\end{array}$ \\
\hline
\end{tabular}

In the HEAL report, the total costs in the EU related to exposure to endocrine disruptors are assessed to EUR 13-31 billion/year (assuming an etiological fraction of 2-5\%). However, this estimate covers a number of diseases that are not included in this project: The HEAL report includes human infertility, cryptorchidism and hypospadias, breast cancer, prostate cancer, autism, ADHD, obesity and diabetes, but it does not include costs associated with testicular cancer. In the HEAL report, it is only 0.5$0.7 \%$ out of the total EUR 31 billion per year that is related to human infertility, cryptorchidism and hypospadias. Even though there are differences in the assumptions between this report and the report from HEAL, the estimated costs related to male reproductive health are roughly similar (table 18). 
The HEAL estimate of the total costs associated with treatment of infertility, cryptorchidism and hypospadias is EUR 3.3-4.4 billion/year, and when using an etiological fraction of $2 \%$ this corresponds to EUR 6687 million/year. Our 2\% etiological fraction estimate of these three conditions is 35 million euro/year. A big difference between the methods used is that HEAL includes all cases of assisted reproduction (ART), whereas we have focused only on the cases which are due to male infertility problems. Another difference between our report and the report from HEAL is that for human infertility, cryptorchidism and hypospadias, HEAL estimate only direct costs, whereas we include also indirect costs (for cryptorchidism, hypospadias and testicular cancer) and intangible costs. Furthermore, we use discounted costs, which does not seem to be the case in the HEAL report. The undiscounted costs (which estimate the costs today arising from past exposure to endocrine disruptors) would in or report be more than twice as high as the discounted, leadin to very similar estimates between our report and HEAL's.

In conclusion, this report focus on negative effects on male reproductive health, which only is a small fraction of the total negative effects of endocrine disruptors, as illustrated by the estimations in the HEAL report.

\subsection{Discussion on uncertainty - sensitivity analysis}

In the summary of the results above we mainly focus on presenting cost estimates at different levels of assumed etiological fractions. In the following section we discuss the general uncertainty of the estimates done in this project and how these affects the overall model cost estimates.

First, the selection of the etiological fraction is a fundamental decision. Since all the costs are measured as an average cost of one incidence of illness this affects the whole cost estimate in a very direct way. The estimates in Table 16 and 17 are based on the estimate of etiological fraction of $20 \%$ that we have used as the medium assumed etiological fraction in this project. Figure 12 illustrate the aggregate cost estimates of the different cost types for the Nordic countries and how these vary when assuming different etiological fractions. 
Figure 12 - Sensitivity of cost estimates due to uncertainity of etiological fraction (Millions of Euros/year of exposure, Discounted estimates)

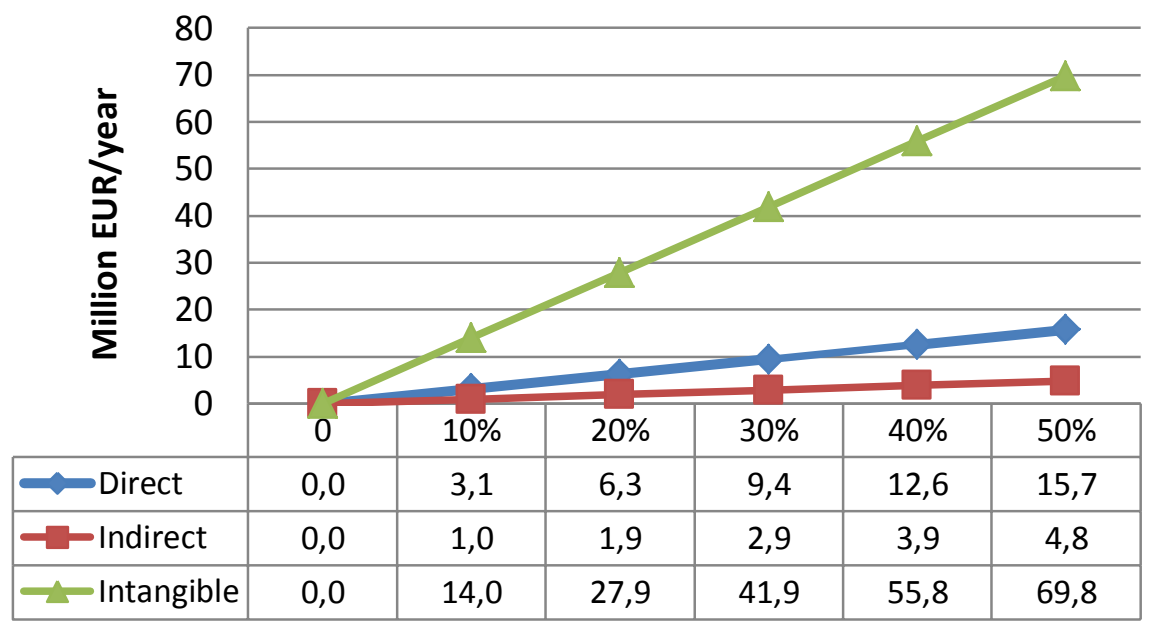

Comment: The figure above illustrates the sensitivity and the level of cost estimates at different assumed levels of etiological fractions.

The incidence rates are related to some uncertainity, especially for infertility due to low semen quality since this condition is quite common, but where there is no central registry of the prevalence. The incidence rate for cryptorchidism is based on Swedish data, and then extrapolated to the other Nordic countries and to the rest of EU-28. The reliability of this assumption depends on how generalizable the Swedish incidence rate is. The incidence rates for testicular cancer and hypospadias are obtained from databases with country specific data (Norcan, Cancer Research UK, \& EUROCAT) and should, thus, be relatively reliable.

The direct costs for Sweden are associated with the least uncertainty since it is derived from registry data from Swedish hospitals. There is however uncertainty involved when extrapolating these estimate to the Nordic countries and to the EU. Average EU treatment costs are probably lower than in Sweden, due to e.g. lower labor costs. There could also be differences in terms of treatment procedures that affect the direct costs.

Alternative cost estimates from Denmark (Almstrup 2014), and how these estimates would affect the total costs are presented in Table 19. Almstrups cost estimates differ substantially from the estimates used in this report, especially for testicular cancer where Almstrups estimates are more than three times higher. As the direct costs are only a small part of the total costs, and since Almstrups estimates for hypospadias and cryptorchidism are lower than those used in this report, using 
Almstrups estimates instead, would have marginal effects ( $1 \%$ increase) on the total costs, as illustrated in table 19.

Table 19. Total discounted costs in the Nordic countries at an etiological fraction of $20 \%$ from two different estimate sources for direct costs (EUR)

\begin{tabular}{lrr} 
Direct cost per case & $\begin{array}{r}\text { Estimates used in this } \\
\text { report }\end{array}$ & $\begin{array}{r}\text { Estimates from Alm- } \\
\text { strup 2014 }\end{array}$ \\
Testicular cancer & 9,800 & 33,500 \\
Hypospadias & 10,300 & 6,800 \\
Cryptorchidism & 4,400 & 3,200 \\
Total discounted costs in Nordic countries at an & 36.1 million & 36.5 million \\
etiological fraction of 20\% & & \\
\hline
\end{tabular}

The estimates of indirect costs are somewhat uncertain since they are based on expert opinion rather than registry data. It is hard for an expert to estimate an average treatment scheme (especially in the case of treatment of testicular cancer, due to its relatively complex treatment process). Unfortunately, we do not have a reference to compare against in the case of dealing with uncertainity of the estimates of hours of production losses for different treatment schemes.

Intangible costs are associated with great uncertainity since measures of quality of life are inherently uncertain. A number of papers discuss the validity of quality of life measures, but no complete consensus is yet reached on how to measure the intangible costs. The most widely used measure is QALY. The validity of a QALY estimate might vary from country to country and greatly depends on how successful the treatment is. Therefore the extrapolation of QALY-measures from one country to another might give an uncertain measure. In the case of the illnesses analysed in this report, there are few QALY-measures available. For testicular cancer there is an alternative QALY-loss estimate (see footnote in Table 6). This alternative estimate implies that 1.98 (rather than 1.09) QALYs are lost per case, and if this estimate was used, then the total discounted costs per year in the Nordic countries at an etiological fraction of $20 \%$ would increase from EUR 36 million to EUR 49 million.

The monetary value per QALY may also create additional uncertainty of the estimates. The valuation standards from ECHA guidelines (ECHA 2008) used in this report gives a high and low reference value. The high reference value meant for sensitivity analysis is estimated at a level more than twice as high (EUR 158,000) as the average reference value used in this report (EUR 70,000). If the high reference value was used, the total discounted costs per year in the Nordic countries at an etiological fraction of $20 \%$ would increase from EUR 36 million to EUR 71 million. 
Another uncertainty regarding the intangible costs is due to the fact that these have not been quantified for male infertility. This leads to an underestimation of the intangible costs.

The assumed timing of the incidence and their accompanying costs, as well as the discount rates used, is also an important factor. Due to the long timescales used for infertility and testicular cancer in this report, the costs related to these illnesses are sensitive to the choice of discount rate. The costs for hypospadias and cryptorchidism are also affected by the choice of discount, but to a considerably smaller degree. If we decrease the human exposure to endocrine distruptors the effects on hypospadias and chryptorchidism will probably be quite immediate since the illness occurs in the infant. In tables 20 and 21 the impact on the total costs from varying the discount rates used tangible and intangible costs, respectively, are presented.

A discount rate for tangible costs of $8 \%$ decreases the total costs by a tenth, while no discounting (i.e. a rate of $0 \%$ ) of the tangible costs increases the total costs by more than a third.

Table 20. Effect on total costs - in the Nordic countries at an etiological fraction of $\mathbf{2 0 \%}-$ from changing the discount rate used for tangible costs (million EUR and \%)

$\begin{array}{lllllll}\text { Discount rate } & 0 \% & 1 \% & 2 \% & 3 \% & 4 \% & 5 \%\end{array}$

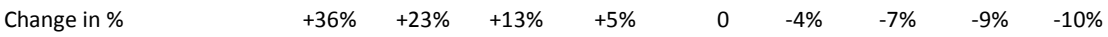

Varying the discount rate used for intangible costs has more substantial effects (which is expected since the intangible costs make up most of the total costs). Increasing the rate to $3 \%$, decreases the total costs of illness by $36 \%$. If, on the other hand, the intangible costs were not discounted at all the costs would be $78 \%$ higher than they are when the rate of $1.5 \%$ is used.

Table 21 Effect on total costs - in Nordic countries at an etiological fraction of $20 \%$ - from changing the discount rate used for intangible costs (million EUR and \%)

\begin{tabular}{lrrrrrrr} 
Discount rate & $0 \%$ & $0.5 \%$ & $1.0 \%$ & $1.5 \%$ & $2.0 \%$ & $2.5 \%$ & $3.0 \%$ \\
Change in million EUR & +28.4 & +16.3 & +7.1 & 0 & -5.5 & -9.8 & -13.2 \\
Change in \% & $+78 \%$ & $+45 \%$ & $+20 \%$ & 0 & $-15 \%$ & $-27 \%$ & $-36 \%$ \\
\hline
\end{tabular}

The undiscounted costs are given by the aggregate change in the $0 \%$ column in tables 20 and 21 . The undiscounted costs are more than twice as large as the reported discounted costs (using $4 \%$ and $1.5 \%$ respectively for tangible and intangible costs). At an etiological fraction of $20 \%$, the total undiscounted costs of yearly exposure are estimated to be EUR 77 million in the Nordic countries and EUR 1,267 million in EU-28. 



\section{Conclusions}

This report estimates the costs of endocrine disruptors related to effects on male reproductive health. This is done using an incidence based model and assumptions of etiological fractions according to expert statements and estimations.

The overall estimates of the cost of illness related to negative effects on human male reproduction due to the present yearly exposure to endocrine disruptors in the Nordic countries (Denmark, Finland, Iceland, Norway and Sweden) amount to a low and a medium estimate of approximately €3.6, 36 and 72 million per year of exposure respectively (etiological fraction of $2 \%$, $20 \%$ and $40 \%$, respectively). Extrapolated to the EU-28, the total costs amounts to €59, 592 and nearly 1200 million per year respectively (etiological fraction of $2 \%, 20 \%$ and $40 \%$, respectively). However, intangible costs of infertility, which have not been included, can be substantial.

The estimated costs above are discounted values; the undiscounted costs are more than twice as high. At an etiological fraction of $20 \%$, the total undiscounted costs of yearly exposure are estimated to be EUR 77 million in the Nordic countries and EUR 1,267 million in EU-28.

It should be kept in mind that this report focuses on only a small part of the various negative health effects, which have been linked to endocrine disruptors. In a recent report from HEAL (2014), the total human health-related costs in the EU induced by exposure to endocrine disruptors are assessed to be EUR 13-31 billion/year (etiological fraction 25\%). In the HEAL report, it is only 0.5-0.7 \% (EUR 66-87 million/year) out of the total EUR 13-31 billion per year that is related to human infertility, cryptorchidism and hypospadias. The results from the HEAL report substantiate that if the costs related to all effects of exposure to endocrine disruptors (i.e. effects in wildlife, increased occurrence of other hormonally-related cancers (e.g. breast- and prostate cancer), behavioral changes, metabolic disorders like obesity and diabetes and suppression of the immune system) were included, the total costs related to endocrine disruptors would be substantially higher than estimated in this report. Further, even though there are differences in the assumptions between this report and the report from HEAL, the estimated costs related to male reproductive health are roughly similar. 
Assuming that endocrine disruptors lead to a number of negative effects on human health and for wildlife, this report substantiate that minimizing exposure to endocrine disruptors will not only remove distress and pain for the persons (and the wildlife) affected, it will also save the society from considerable economic costs. Some of the steps that could lead to reduced exposure to substances with these effects are 1) development of strict scientifically based criteria for the identification of endocrine disruptors and implementation of these in relevant EU legislation, 2) enhancement of the standard information requirements in relevant EU legislation to also comprise information on endocrine disruptive properties, 3) screening of substances for suspected endocrine disrupting properties based on available data, 4) specific testing of suspected endocrine disruptors in order to assess their endocrine disrupting potential, and 5) regulation aimed at minimizing exposure to identified endocrine disruptors. 


\section{References}

Aksglaede L et al. (2009) Recent Decline in Age at Breast Development. Pediatrics 123 (5): e932-e939 (2009). http://dx.doi.org/10.1542/peds.2008-2491

Andersson A-M et al. (2008) Adverse trends in male reproductive health: we may have reached a crucial "tipping point". International Journal of Andrology, 2008 April; 31(2): 74-80. http://dx.doi.org/10.1111/j.1365-2605.2007.00853.x

Aanesen A. and Gottlieb C (2002) Utredning av den infertile mannen eftersatt. Karolinska Institutet.

Akker, van den, et al., (2013) Management of Undescended Testis: A Decision Analysis. Med Decis Making 2013 33: 906 originally published online 2 July 2013.

Akre, o. and Richiardi, L. (2009). Does a testicular dysgenesis syndrome exist? Hum Reprod 24: 2053-2060.

Almstrup (2014) Unpublished estimate by Kristian Almstrup, PhD, Rigshospitalet, after internal communication at Rigshospitalet, Denmark.

Bernfort et al. (2012) QALY som effektmått inom vården - Möjligheter och begränsningar. CMT Rapport 2012:2

Boisen KA et al. (2004): Difference in prevalence of congenital cryptorchidism in infants between two Nordic countries. The Lancet, vol 363, april 17, 2004.

Boisen KA et al. (2005): Hypospadias in a Cohort of 1072 Danish Newborn Boys: Prevalence and Relationship to Placental Weight, Anthropometrical Measurements at Birth, and Reproductive Hormone Levels at Three Months of Age. The Journal of Clinical Endocrinology \& Metabolism, July 1, 2005 vol. 90 no. 7 4041-4046. http://dx.doi.org/10.1210/jc.2005-0302

Cancer research UK (2014), Incidence of Testicular Cancer in European Countries. Avalable online at: http://www.cancerresearchuk.org/cancer-info/ cancerstats/types/testis/incidence/. Information obtained 2014-09-12.

Christiansen, S. et al. (2008): Combined exposure to anti-androgens causes markedly increased frequencies of hypospadias in the rat. International journal of andrology, Volume 32, Issue 2, p.241-248, http://onlinelibrary.wiley.com/ doi/10.1111/j.1365-2605.2008.00866.x/pdf, http://dx.doi.org/10.1111/j.13652605.2008.00866.x

Christiansen, T. et al (2013) Costs of medically assisted reproduction treatment at specialized fertility clinics in the Danish public health care system: results from a 5year follow-up cohort study. Acta Obstetricia et Gynecologica Scandinavica 93 (2014) 64-72. http://dx.doi.org/10.1111/aogs.12293

Czene K. et al. (2002): Environmental and heritable causes of cancer among 9.6 million individuals in the Swedish Family-Cancer Database. Int J Cancer. 2002 May 10;99(2):260-6. http://dx.doi.org/10.1002/ijc.10332

Danish EPA (2012) Exposure of pregnant women to endocrine disruptors in consumer products, Survey of chemicals in consumer products no.117, http://www2.mst.dk/Udgiv/publications/2012/04/978-87-92903-02-0.pdf

ECHA (2008) Guidance on Socio-Economic Analysis - Restrictions, http://www.echa.europa.eu/documents/10162/13641/sea_restrictions_en.pdf 
Eisenberg, ML et al. (2014) The relationship between male BMI and waist circumference on semen quality: data from the LIFE study. Hum Reprod. 2014 Feb;29(2):193-200. http://dx.doi.org/10.1093/humrep/det428

European Commission (2009) Impact Assessment Guidelines. Available at: http://ec.europa.eu/smart-regulation/impact/commission_guidelines/ docs/iag_2009_en.pdf

Eurocat (2014) European Surveillance of Congenital anomalities. Database on prevalence of congenital disorders. Available at; http://www.eurocat-network.eu/ accessprevalencedata/prevalencetables

Eurostat, 2014. Population statistiscs database. Available at: http://epp.eurostat.ec.europa.eu/portal/page/portal/population/introduction Data retrieved 2014-04-03.

Granberg et al. (1995) Couples willingness to pay for IVF/ET. Department of obstetrics and gynecology. Sahlgrenska university hospital.

Hass et al. (2007) Combined Exposure to Anti-Androgens Exacerbates Disruption of Sexual Differentiation in the Rat. Environmental Health Perspect., 2007 Dec., 115, Suppl.1:122-8, http://www.ncbi.nlm.nih.gov/pubmed/18174960 http://dx.doi.org/10.1289/ehp.9360

HEAL (2014) Health costs in the European Union - How much is related to EDCs? http://www.env-health.org/IMG/pdf/18062014_final_health_costs_in_ the_european_union_how_much_is_realted_to_edcs.pdf

Jacobsen R. et al. (2006): Trends in testicular cancer incidence in the Nordic countries, focusing on the recent decrease in Denmark. International Journal of Andrology, 2006 Feb; 29(1):199-204. http://dx.doi.org/10.1111/j.1365-2605.2005.00605.x

Jacobsen PR. et al. (2012) Persistent developmental toxicity in rat offspring after low dose exposure to a mixture of endocrine disrupting pesticides. Reprod Toxicol. 2012 Sep; 34(2):237-50. http://dx.doi.org/10.1016/j.reprotox.2012.05.099

Jensen et al. (2012) QSAR model for androgen receptor antagonism - Data from CHO Cell reporter gene Assays. J Steroid Horm Sci 2012, S:2, http://www.omicsonline.org/2157-7536/2157-7536-S2-006.digital/ 2157-7536-S2-006.html

Jentik et al. (2012) Economic evaluation of anti-epileptic drug therapies with specific focus on teratogenic outcomes. Journal of Medical Economics Vol. 15, No. 5, 862-868. http://dx.doi.org/10.3111/13696998.2012.684366

de Kort, CA et al. (2011) Relationship between maternal dietary patterns and hypospadias. Paediatr Perinat Epidemiol. 2011 May;25(3):255-64.

http://dx.doi.org/10.1111/j.1365-3016.2011.01194.x

Kortenkamp A. et al. (2012) State of the Art Assessment of Endocrine Disrupters, Annex 1, State of the Science. (Revised version, 29 January 2012).

Kortenkamp A. et al. (2014) Mind the gap: can we explain declining male reproductive health with known antiandrogens? Reproduction. 2014 Mar 2;147(4):515-27. http://dx.doi.org/10.1530/REP-13-0440,

http://www.ncbi.nlm.nih.gov/pubmed?term=Scholze\%20M\%5BAuthor\%5D\&caut hor=true\&cauthor_uid=24435164, http://www.ncbi.nlm.nih.gov/pubmed?term= Kortenkamp\%20A\%5BAuthor\%5D\&cauthor=true\&cauthor_uid=24435164

KPP database (Cost Per Patient) (2014) Database of costs associated with healthcare on Swedish hostpitals. Administered by the Swedish Association of Local Authorities and Regions (SKL). Available at: https://stat.skl.se/kpp/index.htm. Information obtained 2014-03-21 
Lund L. et al. (2009) Prevalence of Hypospadias in Danish Boys: A Longitudinal Study, 1977-2005. European Urology 2009 | 55 | 5 | 1022-1026

Mahajan N.N (2007) Biopsychosocial associated of infertility related distress and treatment outcomes. University of Adalaide.

The National Board of Health and Welfare (2009) Sexuell och reproduktiv hälsa.

The National Board of Health and Welfare (Socialstyrelsen) (2011) - Nationellt kvalitetsregister för assisterad befruktning. Behandlingsresultat.

Nygren KG. and Lazdane G. (2006) The European magazine of for sexual and reproductive health "Low fertility - the future of Europe.

Nordcan (2014) (Nordic cancer registry) Association of Nordic Cancer Registries publicly. Available at: http://www-dep.iarc.fr/NORDCAN/english/frame.asp. Information obtained 2014-03-21

OECD (2012) DRP no.178. Detailed Review Paper on the State of the Science on Novel in Vitro and In Vivo Screening and Testing Methods and Endpoints for Evaluating Endocrine Disruptors.

OECD (2014) Unit Labour Cost (ULC), Database available at: http://stats.oecd.org/WBOS/ Default.aspx?QueryName $=427 \& Q u e r y T y p e=V i e w \&$ Lang $=$ en

Patientregistret (2014) (Swedish National Patient Register) Volume of patient contact in Swedish Hospitals. Database administrered by the Swedish Board of Heath and Welfare. Available at http://www.socialstyrelsen.se/register/ halsodataregister/patientregistret. Information obtained 2014-03-21.

Q-IVF registry (2011) (administred by Uppsala Clinical Research Center), Behandlingsresultat Riket.

Ramlau-Hansen, CH et al. (2007a) Subfecundity in overweight and obese couples. Hum Reprod. 2007 Jun;22(6):1634-7. Epub 2007 Mar 7. http://dx.doi.org/10.1093/ humrep/dem035

Ramlau-Hansen, CH et al. (2007b), Is prenatal exposure to tobacco smoking a cause of poor semen quality? A follow-up study. Am J Epidemiol. 2007 Jun 15;165(12):13729. Epub 2007 Mar 16. http://dx.doi.org/10.1093/aje/kwm032

Ramlau-Hansen, CH et al. (2007c), Is smoking a risk factor for decreased semen quality? A cross-sectional analysis. Hum Reprod. 2007 Jan;22(1):188-96. Epub 2006 Sep 11. http://dx.doi.org/10.1093/humrep/del364

Ruark, E et al. (2013) Identification of nine new susceptibility loci for testicular cancer, including variants near DAZL and PRDM14. Nature Genetics, Volume 45 (Number 6) pp 686-689, Nature Publishing Group http://dx.doi.org/10.1038/ng.2635

Scarborough, H (2010) Decomposing the Social Discount Rate. Australian Agricultural and Resource Economics Society, 2010 Conference (54th), February 10-12, 2010, Adelaide, Australia.

Schönbucher et al. (2008) Psychosocial adjustment, healthrelated quality of life, and psychosexual development of boys with hypospadias: a systematic review. J Pediatr Psychol 2008;33:520-35. http://dx.doi.org/10.1093/jpepsy/jsm098

Sharpe RM (2010) Environmental/lifestyle effects on spermatogenesis. Philos Trans R Soc Lond B Biol Sci. 2010 May 27;365(1546):1697-712. http://dx.doi.org/ 10.1098/rstb.2009.0206

Statistics Sweden (2014) Befolkningsstatistik 2013.

Spiegel, U. et al. (2013) Economic implications of in vitro fertilization using willingness to pay. Journal of Public Health (2013) 21:535-557. http://dx.doi.org/

$10.1007 / \mathrm{s} 10389-013-0582-7$ 
Stiggelbout AM et al. (1994) Utility Assessment in Cancer Patients - Adjustment of Time Tradeoff Scores for the Utility of Life Years and Comparison With Standard Gamble Scores. Svanberg A (2003) The long and winding road. Uppsala University.

Swedish Patient Register - see Patientregistret (2014) above.

Toppari J. et al. (2001). Trends in the incidence of cryptorchidism and hypospadias, and methodological limitations of registry-based data. Human Reproduction Update, 7:282-286. http://dx.doi.org/10.1093/humupd/7.3.282

Vårdguiden, (2013) Ofrivillig barnlöshet. Availble at (Swedish): http://www.1177.se/ Stockholm/Fakta-och-rad/Sjukdomar/Ofrivillig-barnloshet/?ar=True

WHO/IPCS (2002): Global Assessment of the State-of-the Science of Endocrine Disruptors. WHO, Geneva.

WHO (2012): Endocrine disrupters and child health. Possible developmental early effects of endocrine disrupters on child health.

WHO/UNEP (2012) State of the science of endocrine disrupting chemicals 2012.

Edited by Åke Bergman, Jerrold J. Heindel, Susan Jobling, Karen A. Kidd and R. Thomas Zoeller.

WHO (2014) Sexual and reproductive, Infertility definitions and, terminology. http://www.who.int/reproductivehealth/topics/infertility/definitions/en/ 


\section{Sammanfattning}

Exponering för hormonstörande ämnen misstänks leda till en rad negativa effekter på människors hälsa och hos vilda djur, inklusive minskad fertilitet, ökad förekomst av hormonrelaterade cancerformer, beteendeförändringar, metabola sjukdomar som fetma och diabetes och nedsatt funktion av immunsystemet. Sådana negativa effekter orsakar inte bara lidande och smärta för personer (och djurliv) som påverkas, utan behandlingen av dessa effekter orsakar också ekonomiska kostnader inte bara för de drabbade, utan även för samhället i stort. Syftet med denna rapport är att ge en uppskattning av de samhällsekonomiska kostnaderna för följderna av exponering för hormonstörande ämnen i den mån det är möjligt.

Vetenskapliga bevis för ett orsakssamband mellan exponering och negativa effekter är emellertid inte lika starkt $\mathrm{i}$ alla fall. I denna rapport har vi fokuserat på negativa effekter på manlig reproduktiv hälsa (kryptorkism, hypospadi, dålig spermakvalitet och testikelcancer) för vilka orsakssamband mellan exponering för hormonstörande ämnen och negativa effekter är förhållandevis väletablerade. De skattade kostnaderna som presenteras i rapporten utgör dock endast en bråkdel av totalkostnaden som kan relateras till exponering för hormonstörande ämnen.

Baserat på den samlade bilden av data från humanepidemiologiskaoch fallstudier, effekter som observerats i vilda djur och effekter som observerats i försöksdjur som exponerats för hormonstörande ämnen är det biologiskt rimligt att anta att det finns ett samband mellan exponering för hormonstörande ämnen och effekter på manlig reproduktiv hälsa. Antagandet att exponering för hormonstörande ämnen leder till negativa hälsoeffekter hos befolkningsgrupper är en grundläggande förutsättning för denna rapport. Syftet med denna rapport har inte varit att dokumentera orsakssambanden.

Uppgifter om kostnaderna för effekterna av exponering för hormonstörande ämnen på manlig reproduktiv hälsa har hämtats från olika källor och baseras på incidenssiffror för testikelcancer, infertilitet (på grund av 
låg spermakvalitet), hypospadi och kryptorkism. Denna information har kombinerats med antaganden om den etiologiska fraktionen. ${ }^{16}$

Förekomsten av olika typer av cancer är välregistrerad i alla de nordiska länderna (i Nordiska cancerregistret, Nordcan 2014), för de övriga hälsotillstånden har olika metoder fått användas för att skatta förekomsten. Vissa är baserade på data från register och några på vetenskapliga studier.

Även om styrkan i bevisningen mellan exponering för hormonstörande ämnen och effekter på manlig reproduktiv hälsa verkar övertygande, är det svårt att uppskatta den etiologiska fraktionen. Därför har vi baserat på tillgänglig kunskap, och efter samråd med experter, valt att använda tre skattningar av etiologisk fraktion för jämförelse i denna rapport, dessa är $2 \%, 20 \%$ och $40 \%$.

\section{Samhällsekonomiska kostnader i Norden (Danmark, Finland, Island, Norge och Sverige)}

De totala kostnadsberäkningarna omfattar direkta materiella kostnader (kostnader för behandling i hälso- och sjukvården), indirekta materiella kostnader (t.ex. sjukledighet från arbetet) och immateriella kostnader (förlust av levnadsår och förlust av livskvalitet). De immateriella kostnaderna för minskad spermakvalitet (till exempel den psykosociala förlusten relaterad till ofrivillig barnlöshet) är dock inte inkluderade på grund av svårigheter att hitta tillförlitliga källor för att kvantifiera dessa aspekter.

De direkta och indirekta kostnaderna har diskonterats med 4\% per år, medan de immateriella kostnaderna diskonteras med en ren tidsprefrensränta på 1,5 \% per år.

Förutsatt en etiologisk fraktion på $20 \%$ blir den diskonterade samhällsekonomiska kostnaden av effekterna på manlig reproduktiv hälsa från den årliga exponeringen för hormonstörande ämnen 36 miljoner EUR i Norden. Antar man en annan etiologisk fraktion kommer att resultaten att ändras proportionellt. En etiologisk fraktion på $2 \%$ ger en årlig totalkostnad på 3,6 miljoner EUR, medan en etiologisk fraktion på $40 \%$ innebär årliga kostnader på 72 miljoner EUR.

Figur 13 summerar de estimerade direkta, indirekta och immateriella kostnaderna per hälsoeffekt i Norden.

16 Etiologisk fraktion = den del av det totala antalet sjukdomsfall som beror på exponering för en särskild faktor, i detta fall hormonstörande ämnen. 
Figure 13- Kostnader för effekter på manlig reproduktion i Norden som följd av exponering för hormonstörande ämnen vid olika nivåer på etiologisk fraktion (miljoner Euro per år)

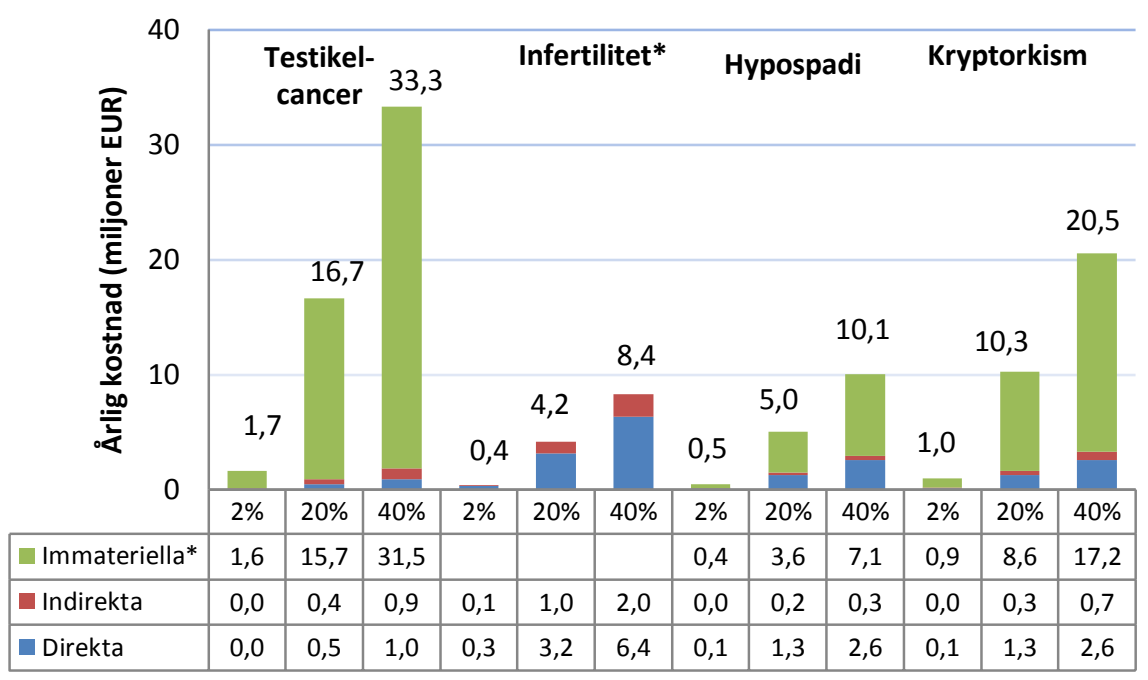

*De immateriella kostnaderna av infertilitet är inte kvantifierade i denna rapport.

De estimerade kostnaderna i figur 13 är diskonterade värden; de odiskonterade värdena är mer än dubbelt så stora. Vid en etiologisk fraktion på $20 \%$ är de odiskonterade kostnaderna av effekterna på manlig reproduktiv hälsa från den årliga exponeringen för hormonstörande ämnen 77 miljoner EUR i Norden.

\section{Samhällsekonomiska kostnader för EU-28}

För att få en uppfattning om kostanderna i EU har vi har extrapolerat de nordiska ländernas kostnader till EU-28. Förutsatt en etiologisk fraktion på $20 \%$ blir den diskonterade samhällsekonomiska kostnaden för EU-28 592 miljoner EUR per år (figur 14). Antar man en annan etiologisk fraktion kommer att resultaten att ändras proportionellt. En etiologisk fraktion på $2 \%$ ger en årlig totalkostnad på 59 miljoner EUR i EU-28, medan en etiologisk fraktion på $40 \%$ innebär årliga kostnader på nästan 1200 miljoner (Figur 14).

De estimerade kostnaderna i figur 14 är diskonterade värden; de odiskonterade värdena är mer än dubbelt så stora. Vid en etiologisk fraktion på $20 \%$ är de odiskonterade kostnaderna av effekterna på manlig reproduktiv hälsa från den årliga exponeringen för hormonstörande ämnen 1267 miljoner EUR i EU-28. 
Figure 14- Kostnader för effekter på manlig reproduktion i Norden som följd av exponering för hormonstörande ämnen vid olika nivåer på etiologisk fraktion (miljoner Euro per år)

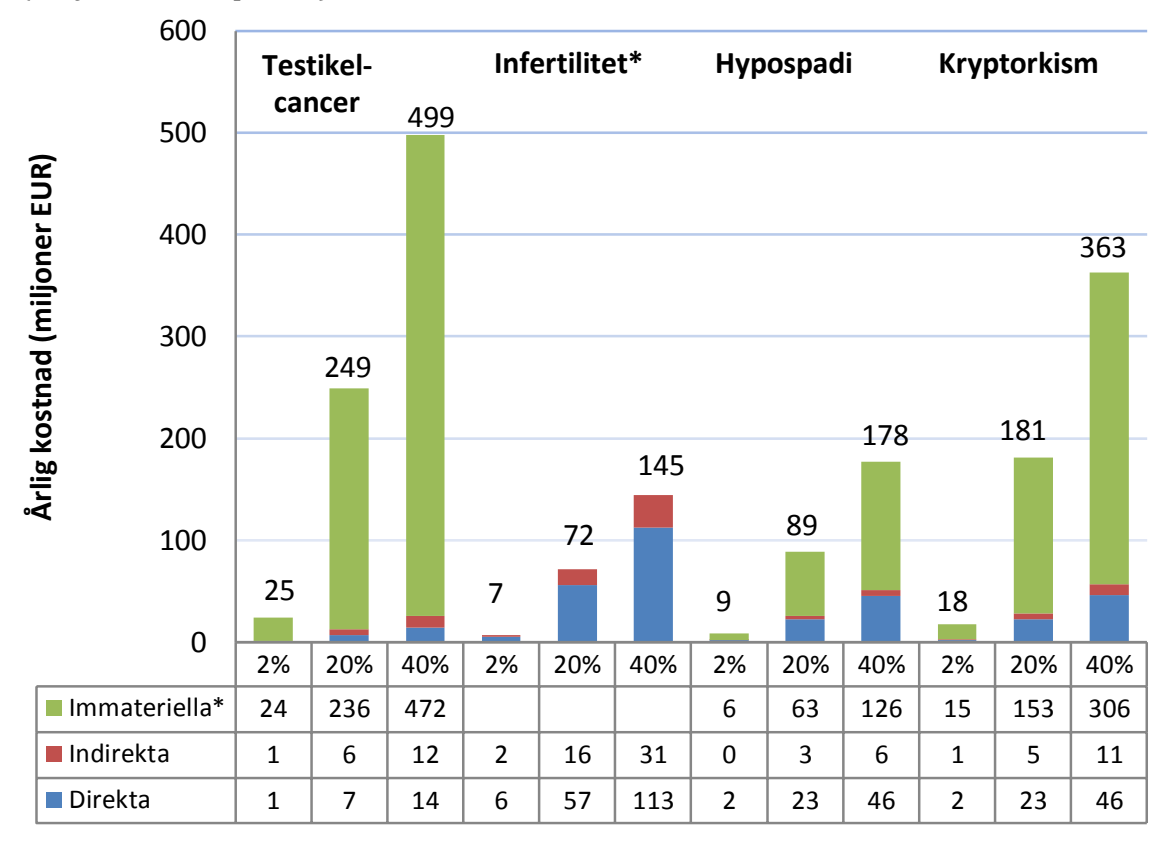

*De immateriella kostnaderna av infertilitet är inte kvantifierade i denna rapport.

\section{Slutsatser}

De totala samhällsekonomiska kostnaderna relaterade till negativa effekter på manliga reproduktiv hälsa till följd av exponering för hormonstörande ämnen i de nordiska länderna (Danmark, Finland, Island, Norge och Sverige) uppgår till cirka 36 miljoner EUR per år, förutsatt att $20 \%$ av fallen beror på exponering för hormonstörande ämnen (etiologiska fraktionen). Om den låga etiologiska fraktionen (2\%) antas, uppgår de totala kostnaderna i Norden till cirka 3,6 miljoner EUR per år, och om den höga etiologiska fraktionen (40 \%) antas, uppgår de totala kostnaderna till 72 miljoner EUR per år. Dessa uppskattningar inkluderar inte immateriella kostnader för infertilitet. De totala kostnaderna är därför sannolikt underskattade.

Extrapolering till EU-28 ger kostnader på nära 600 miljoner EUR per år, etiologiska fraktionen på 20 \% (59 miljoner EUR per år med etiologiska fraktion av $2 \%$ och nästan EUR 1200 miljoner per år med en etiologisk fraktion av $40 \%$ ). Uppskattningarna för EU-28 är baserade på en relativt enkel extrapolering av resultat från beräkningarna för de nordiska länderna och är därför mer osäkra än resultaten för de nordiska länderna. 
De estimerade kostnaderna ovan är diskonterade värden; de odiskonterade värdena är mer än dubbelt så stora.

Det bör hållas i minnet att denna rapport fokuserar på endast en liten del av de olika negativa hälsoeffekter, som har kopplats till exponering för hormonstörande ämnen. Om kostnaderna för effekter i djurlivet, ökad förekomst av andra hormonrelaterade cancerformer (t.ex. bröstoch prostatacancer), andra hormonella sjukdomar som polycystiskt ovarie syndrom och andra kvinnliga reproduktionsstörningar, beteendeförändringar, metabola sjukdomar, som fetma och diabetes, och nedsatt av immunförsvar relaterade till exponering för hormonstörande ämnen så skulle beloppen vara mycket högre än de som presenteras i den här rapporten. Nyligen har kostnaderna för exponering för hormonstörande ämnen uppskattats till 13-31 miljarder EUR per år i EU (HEAL 2014). Denna uppskattning är fokuserad på kostnader idag orsakade av tidigare exponering för hormonstörande ämnen och är därför inte diskonterad. Rapporten omfattar kostnader för human infertilitetsbehandling, kryptorkism, hypospadi, bröstcancer, prostatacancer, ADHD, autism, övervikt, fetma och diabetes, med antagande av en etiologisk fraktion på 2$5 \%$ (HEAL, 2014). ${ }^{17}$ I HEAL-rapporten är bara $0,5-0,7 \%$ av dessa kostnader relaterade till mänsklig infertilitet, kryptorkism och hypospadi. Detta understryker ytterligare att siffrorna i denna rapport troligen bara visar en bråkdel av de totala kostnaderna för hälsoeffekter av hormonstörande ämnen.

Denna rapport visar (givet att hormonstörande ämnen leder till en rad negativa effekter på människors hälsa) att en minimering av exponering för hormonstörande ämnen inte bara lindrar oro och smärta för de individer som berörs, utan även leder till betydande minskningar av samhällsekonomiska kostnader. Några av de åtgärder, som kan leda till en minskad exponering för ämnen med dessa effekter är 1) utveckling av strikta vetenskapliga kriterier för identifiering av hormonstörande ämnen och genomförandet av dessa i relevant EU-lagstiftning, 2) förbättring av standardinformationskraven i relevant EU-lagstiftning så att även uppgifter om hormonstörande egenskaper omfattas, 3) screening av ämnen för misstänkt hormonstörande egenskaper utifrån tillgängliga data, 4) särskild testning av misstänkta hormonstörande ämnen i syfte att bedöma deras hormonstörande potential och 5) regleringar som syftar till att minimera exponeringen för identifierade hormonstörande ämnen.

${ }^{17} \mathrm{HEAL}=$ Health and Environment Alliance, en europeisk intresseorganisation 



\section{Appendix A - Summary of data sources}

\begin{tabular}{|c|c|c|c|c|c|}
\hline & Expert interview & $\begin{array}{l}\text { Direct health care } \\
\text { costs }\end{array}$ & $\begin{array}{l}\text { Indirects } \\
\text { costs }\end{array}$ & $\begin{array}{l}\text { Intangible } \\
\text { costs }\end{array}$ & Incidence \\
\hline Hypospadias & $\begin{array}{l}\text { Agneta Nordenskjöld, } \\
\text { Professor of pedriat- } \\
\text { ric surgery, Karolin- } \\
\text { ska University } \\
\text { Hospital* }\end{array}$ & $\begin{array}{l}\text { Cost estimates for } \\
\text { health care related } \\
\text { to diagnosis in } \\
\text { Sweden (KPP- } \\
\text { database and } \\
\text { Swedish patient } \\
\text { registry) }\end{array}$ & $\begin{array}{l}\text { Interviews } \\
\text { with } \\
\text { experts on } \\
\text { expected } \\
\text { sick leave } \\
\text { due to } \\
\text { treatment. }\end{array}$ & $\begin{array}{l}\text { QALY meas- } \\
\text { ure } \\
\text { (Schönbuche } \\
\text { ret al. 2008) }\end{array}$ & $\begin{array}{l}\text { Incidence rates from } \\
\text { EUROCAT database, } \\
\text { along with estimates } \\
\text { from the Swedish } \\
\text { patient registry and } \\
\text { birth data from } \\
\text { Eurostat }\end{array}$ \\
\hline Cryptorchidism & $\begin{array}{l}\text { Claude Kollin special- } \\
\text { ist in pedriatric } \\
\text { surgery at , Karolin- } \\
\text { ska University } \\
\text { Hospital* }\end{array}$ & $\begin{array}{l}\text { Cost estimates for } \\
\text { health care related } \\
\text { to diagnosis in } \\
\text { Sweden (KPP- } \\
\text { database and } \\
\text { Swedish patient } \\
\text { registry) }\end{array}$ & $\begin{array}{l}\text { Interviews } \\
\text { with } \\
\text { experts on } \\
\text { expected } \\
\text { sick leave } \\
\text { due to } \\
\text { treatment. }\end{array}$ & $\begin{array}{l}\text { QALY measu- } \\
\text { re (van den } \\
\text { Akker et al. } \\
\text { 2013) }\end{array}$ & $\begin{array}{l}\text { Incidence rates from } \\
\text { the Swedish patient } \\
\text { registry and birth } \\
\text { data from Eurostat }\end{array}$ \\
\hline Testicular cancer & $\begin{array}{l}\text { Sophie Dorothea } \\
\text { Fosså Professor } \\
\text { dr.med. expert in } \\
\text { testicular cancer, } \\
\text { Nasjonalt kompetan- } \\
\text { sesenter for senef- } \\
\text { fekter etter kreftbe- } \\
\text { handling, Olso } \\
\text { universitetssykehus* }\end{array}$ & $\begin{array}{l}\text { Cost estimates for } \\
\text { health care related } \\
\text { to diagnosis in } \\
\text { Sweden (KPP- } \\
\text { database and } \\
\text { Swedish patient } \\
\text { registry) }\end{array}$ & $\begin{array}{l}\text { Interviews } \\
\text { with } \\
\text { experts on } \\
\text { expected } \\
\text { sick leave } \\
\text { due to } \\
\text { treatment. }\end{array}$ & $\begin{array}{l}\text { QALY measu- } \\
\text { re (Stiggel- } \\
\text { bout et al. } \\
\text { 1994) }\end{array}$ & $\begin{array}{l}\text { Nordcan registry for } \\
\text { data on incidence } \\
\text { rates in the Nordic } \\
\text { countries, Cancer } \\
\text { Research UK } 2014 \text { for } \\
\text { estimates of inci- } \\
\text { dence in EU coun- } \\
\text { tries }\end{array}$ \\
\hline Infertility & $\begin{array}{l}\text { Göran Westlander, } \\
\text { MD, head of depart- } \\
\text { ment for fertilization } \\
\text { treatment at Car- } \\
\text { landerska Hospital in } \\
\text { Gothenburg* }\end{array}$ & $\begin{array}{l}\text { Estimates of health } \\
\text { care contacts due } \\
\text { to low semes } \\
\text { quality by expert } \\
\text { and estimation } \\
\text { based on number } \\
\text { of contacts }\end{array}$ & $\begin{array}{l}\text { Interviews } \\
\text { with } \\
\text { experts on } \\
\text { expected } \\
\text { sick leave } \\
\text { due to } \\
\text { treatment. }\end{array}$ & $\begin{array}{l}\text { Intangible } \\
\text { costs of } \\
\text { infertility } \\
\text { have not } \\
\text { been quanti- } \\
\text { fied in this } \\
\text { project. }\end{array}$ & $\begin{array}{l}\text { Same fraction for all } \\
\text { of Europe, based on } \\
\text { several studies } \\
\text { combined with } \\
\text { population data from } \\
\text { Eurostat. }\end{array}$ \\
\hline $\begin{array}{l}\text { Completing } \\
\text { remarks/data }\end{array}$ & $\begin{array}{l}\text { Overall model } \\
\text { checked by Olle } \\
\text { Söder, Professor in } \\
\text { pediatric surgery at } \\
\text { Karolinska University } \\
\text { Hospital** }\end{array}$ & & $\begin{array}{l}\text { Hourly } \\
\text { labor cost } \\
\text { in OECD- } \\
\text { countries }\end{array}$ & $\begin{array}{l}\text { Valuation of } \\
\text { QALY accord- } \\
\text { ing to } \\
\text { standard } \\
\text { value in EU- } \\
\text { guidelines for } \\
\text { SEA }\end{array}$ & \\
\hline
\end{tabular}

* Has been interviewed, and has overviewed assumptions on incidence rate for Sweden and loss of working hours.

**Has reviewed basic assumptions for the study. 



\section{Appendix B - Treatment schemes}

In the process of calculating the cost of illness for the different diseases in this report we have created standard models for the treatment and the loss of production time due to contact with health care. These models have several purposes.

First we created a baseline model in order to understand how the costs or data are divided in the time of treatment. With this we have the possibility of making reliability checks of the data for the authorities in order to detect possible missing data. The other main purpose is to estimate the other parameters that are not covered by public statistics such as the whole primary health care sector and the production losses due to hospital visits.

\section{Testicular cancer}

Below we show our general model for the general treatment due to one incidence of testicular cancer.

\begin{tabular}{|c|c|c|c|c|c|c|}
\hline \multicolumn{2}{|l|}{ Average for all patients } & \multicolumn{5}{|l|}{ Year } \\
\hline & & 1 & 2 & 3 & $4-7$ & $8-10$ \\
\hline \multirow{6}{*}{$\begin{array}{l}\text { Doctors appointments } \\
\text { (number) }\end{array}$} & Primary health care visits & 2.50 & & & & \\
\hline & Preoperative visits & 2 & & & & \\
\hline & Orchidectomy & 1 & & & & \\
\hline & Chemotherapy treatment & 1.8 & & & & \\
\hline & Check-ups, blood sample & & 3.8 & 3 & 1 & \\
\hline & +MR screening & & 1.9 & 1 & 1 & 1 \\
\hline \multirow[t]{2}{*}{ Sick leave (days) } & In treatment & 29.5 & 4.4 & 3.2 & 1.6 & 0.8 \\
\hline & After treatment & 26 & & & & \\
\hline
\end{tabular}




\begin{tabular}{|c|c|c|c|c|c|c|c|c|}
\hline \multicolumn{9}{|c|}{ General treatment in first year } \\
\hline & & \multicolumn{4}{|c|}{ Number of visits } & \multicolumn{3}{|c|}{ Sick leave (days) } \\
\hline \multirow{2}{*}{\multicolumn{3}{|c|}{$\begin{array}{l}\text { Primary health care visits } \\
\text { Orchidectomy }\end{array}$}} & \multicolumn{3}{|l|}{2.5} & \multicolumn{3}{|r|}{1.5} \\
\hline & & & \multicolumn{3}{|l|}{1} & \multicolumn{3}{|r|}{10} \\
\hline \multicolumn{3}{|c|}{$\begin{array}{l}\text { Five different treatment schemes depending on } \\
\text { process of illness }\end{array}$} & \multicolumn{3}{|c|}{ Yearly } & \multirow[b]{2}{*}{3} & \multirow[b]{2}{*}{$4-7$} & \multirow[b]{2}{*}{$8-10$} \\
\hline For whom? & $\begin{array}{l}\text { Share of } \\
\text { patients }\end{array}$ & Action & Type of cost & 1 & 2 & & & \\
\hline \multirow{5}{*}{$\begin{array}{l}\text { Cancer has spread } \\
\text { (treated with } \\
\text { Cytostatika) }\end{array}$} & \multirow[t]{5}{*}{$50 \%$} & \multirow{3}{*}{$\begin{array}{l}\text { Doctors } \\
\text { appointments }\end{array}$} & \multirow{3}{*}{$\begin{array}{l}\text { Chemotherapy treatment } \\
\text { Check-ups, blood sample } \\
\text { +MR screening }\end{array}$} & 3 & & & \\
\hline & & & & 4 & 3 & 1 & 1 & \\
\hline & & & & 2 & 1 & 1 & 1 & 1 \\
\hline & & \multirow{2}{*}{$\begin{array}{l}\text { Sick leave } \\
\text { (days) }\end{array}$} & In treatment & 35 & 2 & 1 & \multirow[t]{2}{*}{0.875} & \multirow[t]{2}{*}{0.5} \\
\hline & & & After treatment & 40 & 0 & 0 & & \\
\hline \multirow{5}{*}{$\begin{array}{l}\text { No spread, Chemo- } \\
\text { therapy treatment, } \\
\text { open treatment }\end{array}$} & \multirow[t]{5}{*}{$15 \%$} & Doctors & Chemotherapy treatment & 1 & & & & \\
\hline & & \multirow{2}{*}{ appointments } & Check-ups, blood sample & 4 & 3 & 1 & 1 & \\
\hline & & & +MR screening & 1 & 1 & 1 & 1 & 1 \\
\hline & & \multirow{2}{*}{$\begin{array}{l}\text { Sick leave } \\
\text { (days) }\end{array}$} & In treatment & 0.5 & 2 & 1 & 0.875 & 0.5 \\
\hline & & & After treatment & 20 & & & & \\
\hline \multirow{5}{*}{$\begin{array}{l}\text { No spread, Cysto- } \\
\text { statika treatment, } \\
\text { hospital }\end{array}$} & \multirow[t]{5}{*}{$15 \%$} & Doctors & Chemotherapy treatment & 1 & & & & \\
\hline & & \multirow[t]{2}{*}{ appointments } & Check-ups, blood sample & 4 & 3 & 1 & 1 & \\
\hline & & & +MR screening & 1 & 1 & 1 & 1 & 1 \\
\hline & & \multirow{2}{*}{$\begin{array}{l}\text { Sick leave } \\
\text { (days) }\end{array}$} & In treatment & 5 & 2 & 1 & 0.875 & 0.5 \\
\hline & & & After treatment & 20 & & & & \\
\hline \multirow{4}{*}{$\begin{array}{l}\text { No spread, no } \\
\text { treatment }\end{array}$} & \multirow[t]{4}{*}{$20 \%$} & \multirow{3}{*}{$\begin{array}{l}\text { Doctors } \\
\text { appointments }\end{array}$} & Chemotherapy treatment & & & & & \\
\hline & & & Check-ups, blood sample & 3 & 3 & 1 & 1 & \\
\hline & & & +MR screening & 3 & 1 & 1 & 1 & 1 \\
\hline & & $\begin{array}{l}\text { Sick leave } \\
\text { (days) }\end{array}$ & $\begin{array}{l}\text { In treatment } \\
\text { After treatment }\end{array}$ & 3 & 8 & 4 & 3.5 & 2 \\
\hline
\end{tabular}

The model in table B1 is an average of the models of different treatment schemes that we show in table B2. What effects the treatment of testicular cancer is the most if the cancer has spread after the initial orchidectomy. Up until the orchidectomy, the treatment is expected to be the same for everyone.

\section{Hypospadias}

Below we show our general model for the general treatment due to one incidence of hypospadias. 


\begin{tabular}{|c|c|c|c|c|c|}
\hline & & & 1 & $3-5 *$ & $10-15^{*}$ \\
\hline \multirow{5}{*}{$\begin{array}{l}\text { Doctors appo- } \\
\text { intments }\end{array}$} & $100 \%$ & Hypospadias surgery & 1 & & \\
\hline & $60 \%$ & Check up (60\% lighter cases) & & 1.5 & \\
\hline & $40 \%$ & $\begin{array}{l}\text { Check up ( } 3-4 \text { check ups for } 40 \% \\
\text { more severe cases) }\end{array}$ & & & 3.5 \\
\hline & $15 \%$ & Urethrocutane fistula & & 2 & \\
\hline & $10 \%$ & Urethra stricture & & 2 & \\
\hline \multirow[t]{2}{*}{$\begin{array}{l}\text { Parents sick } \\
\text { leave (days) }\end{array}$} & $\begin{array}{l}\text { Average } \\
\text { (for all } \\
\text { patients) }\end{array}$ & In treatment & 0.5 & 2.6 & 0.7 \\
\hline & & After treatment & 4 & & \\
\hline
\end{tabular}

* Number of occurrences is the estimate of the number rather than yearly average like in the section describing testicular cancer.

\section{Cryptorchidism}

Below we show our general model for the general treatment due to one incidence of cryptorchidism. What we mean by incidence is children with cryptorchidism that is treated with surgery. Children with an initial restrained testis but where the state is self-resolving are not included in this study. Since testicular cancer and infertility are both covered as primary effects in this report we will not elaborate on them as secondary effects of cryptorchidism.

\begin{tabular}{llr} 
Table B4 - Chryptorchidism & & Year \\
Action & & $\mathbf{1}$ \\
\hline Doctors appointments(number) & Type of cost & 1 \\
& $\begin{array}{l}\text { Cryptorchidism surgery } \\
\text { Check up }\end{array}$ & 1 \\
Sick leave (days) & In treatment & 1 \\
& After treatment & 2 \\
\hline
\end{tabular}





\section{Appendix C - Additional calculations for infertility}

\section{Incidence references}

Based on the references in table C1 the incidence of male infertility due to reduced semen quality applied in the report is $4 \%$.

\begin{tabular}{|c|c|c|c|c|}
\hline Author & $\begin{array}{r}\text { Infertile } \\
\text { couples (\%) }\end{array}$ & $\begin{array}{r}\text { Male } \\
\text { problem (\%) }\end{array}$ & $\begin{array}{r}\text { Female } \\
\text { problem (\%) }\end{array}$ & $\begin{array}{r}\text { Shared prob- } \\
\text { lem/unexplained } \\
(\%)\end{array}$ \\
\hline Svanberg A. (2003) & $5-10 \%$ & $x$ & $x$ & $x$ \\
\hline Nygren and Lazdane (2006) & $10-12 \%$ & $x$ & $x$ & $x$ \\
\hline $\begin{array}{l}\text { The National Board of Health and } \\
\text { Welfare (2011) }\end{array}$ & $10-15 \%$ & $x$ & $x$ & $x$ \\
\hline Aanesen A. and Gottlieb C. (2002) & $12.5 \%$ & $30 \%$ & $30 \%$ & $40 \%$ \\
\hline Vårdguiden (2013) & $15-20 \%$ & $33 \%$ & $33 \%$ & $33 \%$ \\
\hline
\end{tabular}

\section{Identification of groups}

The table below describes the number of ICSI treatments performed in Sweden 2011(latest data available) and its success rates.

\begin{tabular}{lrrr} 
Table C2 - Initiated ICSI cycles 2011, Sweden & & & \\
& Fresh & Frozen & Total \\
\hline Initiated cycles & 5,619 & 2,591 & 8,210 \\
Births total & 1,280 & 474 & 1,754 \\
Fraction successful births & $23 \%$ & $18 \%$ & $21 \%$ \\
\hline
\end{tabular}

Source: Swedish Q-IVF registry.

Comment: Frozen/Fresh refers to the embryo. 
In order to estimate the number of couples that are helped and how many are not through ICSI treatment we need to estimate the average number of trials before giving up. ${ }^{18}$ Based on our expert Göran Westlander ${ }^{19}$ the probability of successful pregnancy is stationary during cycle 1-3 but probably decreases during the cycles after that. Data has not been found to confirm this but in order to continue the calculations we assume that couples that start fertility treatment undergo up to 5 cycles and that the probability of success is stationary throughout the five cycles. These estimates are based on interviews with our expert and discussions with Q-IVF registry coordinators. The table below describes the probabilities and costs incurred from ICSI treatments.

\begin{tabular}{l|r|rrrr}
\hline \multicolumn{2}{|c}{ Table C3 - Cost of infertility treatment } \\
$\begin{array}{r}\text { Deliviry rate per } \\
\text { Cycle }\end{array}$ & $\begin{array}{r}\text { Cumulative deliviry rate } \\
\text { initiated cycle (\%) }\end{array}$ & Cost (Fresh) & Cost (Frozen) & $\begin{array}{r}\text { Average } \\
\text { cost }\end{array}$ \\
Cycle 1 & $21 \%$ & $21 \%$ & EUR 3,450 & EUR 1,500 & EUR 2,826 \\
Cycle 2 & $21 \%$ & $38 \%$ & EUR 3,450 & EUR 1,500 & EUR 2,826 \\
Cycle 3 & $21 \%$ & $51 \%$ & EUR 3,450 & EUR 1,500 & EUR 2,826 \\
Cycle 4 & $21 \%$ & $62 \%$ & EUR 3,450 & EUR 1,500 & EUR 2,826 \\
Cycle 5 & $21 \%$ & $70 \%$ & EUR 3,450 & EUR 1,500 & EUR 2,826 \\
\hline
\end{tabular}

Comment: Average cost based on fraction of treatment that is frozen and fresh. Probability of success is not taken into account.

Based on the calculations in the table above, $70 \%$ of the couples that engage in ICSI treatment have successful results. Taking into account the probabilities of undergoing each treatment, the average direct medical cost becomes EUR 9,250, described in the table below. Similar results are found by Christiansen et al. (2013) who estimates the direct cost per birth to EUR 8,845.

\footnotetext{
18 There is no data available on number of individuals, only number of treatments.

${ }^{19}$ Head of department, fertilitetscentrum, Göteborg.
} 


\begin{tabular}{|c|c|c|c|}
\hline Cycle & Probability of undergoing cycle & Cost & Average cost \\
\hline Cycle 1 & $100 \%$ & EUR 2,826 & EUR 2,826 \\
\hline Cycle 2 & $79 \%$ & EUR 2,826 & EUR 2,222 \\
\hline Cycle 3 & $62 \%$ & EUR 2,826 & EUR 1,747 \\
\hline Cycle 4 & $49 \%$ & EUR 2,826 & EUR 1,374 \\
\hline Cycle 5 & $38 \%$ & EUR 2,826 & EUR 1,081 \\
\hline SUM & & & EUR 9,250 \\
\hline
\end{tabular}

Source: Q-IVF registry, own estimations.

Worth noting is that these costs only incorporates the direct costs and does not reflect the fact that not all have a successful outcome. Hence, additional calculations are necessary.

Since $70 \%$ of the initiated treatments have successful results it means that $30 \%$ of the treatments are unsuccessful. Since data is only available on the number of treatments each year, not the number of couples that start treatment, we estimate the number of initiated treatments based on the probability of success in each cycle and the maximum number of cycles. The average of all initiated treatments, successful and unsuccessful, becomes 3.27 cycles per initiated ICSI treatment by calculating the following;

We define the two groups that undergo treatment as "successful outcome" and "failure". We have in discussion with expert judgement estimated that a couple starting infertility treatment on average will give up after five cycles if not a baby is concived before the fifth cycle. The probability of success at each cycle is $p(0.21)$ and correspondingly, the probability of failure as $q(0.79)$ the average number of trials (ANT) becomes:

$$
A N T_{A l l}=\mathbf{1} p+2 p q+3 p q^{\wedge 2}+4 p q^{\wedge 3}+5\left(1-p-p q-p q^{\wedge 2}-p q^{\wedge 3}\right)=3.27
$$

Since the number of treatments is 8,210 the result is that 2,508 couples undergo treatment $(8,210 / 3.27)$. Since we want to split up the average number of treatments between attempts with successful outcome and negative outcome one more step is needed. This step is important since the costs incurred are contingent on number of treatments and result. The average number of cycles, given that the outcome is successful in one of the five cycles becomes: 


\section{Cumulative probability of success after 5 cycles $=70 \%$}

$$
p / 0.7=0.31=g
$$

We call the probability of success, given success $g$ and $(1-g)=w$.

$$
A N T_{\text {Success }}=1 g+2 g w+3 g w^{\wedge 2}+4 g w^{\wedge 3}+5 g w^{\wedge 4}=2.53
$$

Hence, the average number of trials given success becomes 2.53. Sum-

\begin{tabular}{|c|c|c|c|}
\hline & Success (Group 1) & Failure (Group 2) & \\
\hline Average number of trials & 2.53 & 5 & \\
\hline Number of couples & 1,754 & 754 & \\
\hline Total & 4,439 & 3,771 & Grand total: 8,210 \\
\hline
\end{tabular}
mirising in the table below to 8210 which is the total number of cycles:

Since we have a total of 8,210 initiated cycles we estimate the number of started attempts to $2,508(8,210 / 3.27)$. As described in the main section there are 4,294 children that would have been conceived if not for reduced semen quality, hence $58 \%(2,508 / 4,294)$ of those babies are attempted to be conceived through ICSI treatment from which $70 \%$ $(1,754)$ are successful and $30 \%(754)$ are not. The remaining $42 \%$ of the children that would have been conceived naturally, if not for infertility, concist of 1,803 children which in this study are refered as to as Group 3. 


\section{Appendix D - Estimated costs per Nordic country and EU-28}

\begin{tabular}{|c|c|c|c|c|c|}
\hline & Cases $(20 \%)$ & Direct costs & Indirect costs & Intangible costs & $\begin{array}{l}\text { Total } \\
\text { costs }\end{array}$ \\
\hline \multicolumn{6}{|c|}{ Testicular cancer } \\
\hline Denmark & 57 & 134 & 115 & 4,390 & 4,639 \\
\hline Finland & 27 & 64 & 55 & 2,087 & 2,206 \\
\hline Iceland & 2 & 4 & 4 & 138 & 146 \\
\hline Norway & 57 & 133 & 157 & 4,374 & 4,665 \\
\hline Sweden & 62 & 145 & 114 & 4,758 & 5,017 \\
\hline Nordic total & 205 & 480 & 444 & 15,748 & 16,672 \\
\hline EU (28) & 3,078 & 7,198 & 5,843 & 236,213 & 249,253 \\
\hline \multicolumn{6}{|l|}{ Infertility } \\
\hline Denmark & 236 & 642 & 189 & Not quantified & 831 \\
\hline Finland & 236 & 642 & 188 & Not quantified & 830 \\
\hline Iceland & 18 & 50 & 15 & Not quantified & 64 \\
\hline Norway & 238 & 648 & 260 & Not quantified & 908 \\
\hline Sweden & 445 & 1,212 & 325 & Not quantified & 1,538 \\
\hline Nordic total & 1,172 & 3,194 & 978 & Not quantified & 4,171 \\
\hline EU (28) & 20,787 & 56,630 & 15,698 & Not quantified & 72,328 \\
\hline \multicolumn{6}{|l|}{ Hypospadias } \\
\hline Denmark & 19 & 194 & 25 & 528 & 747 \\
\hline Finland & 22 & 230 & 29 & 627 & 886 \\
\hline Iceland & 2 & 20 & 3 & 55 & 78 \\
\hline Norway & 27 & 276 & 48 & 751 & 1,075 \\
\hline Sweden & 57 & 585 & 68 & 1,594 & 2,247 \\
\hline Nordic total & 127 & 1,304 & 173 & 3,556 & 5,033 \\
\hline EU (28) & 2,244 & 23,111 & 2,789 & 63,017 & 88,917 \\
\hline \multicolumn{6}{|c|}{ Chryptorchidism } \\
\hline Denmark & 59 & 263 & 66 & 1,732 & 2,061 \\
\hline Finland & 59 & 263 & 66 & 1,733 & 2,062 \\
\hline Iceland & 5 & 20 & 5 & 134 & 159 \\
\hline Norway & 60 & 265 & 91 & 1,748 & 2,103 \\
\hline Sweden & 112 & 496 & 113 & 3,272 & 3,882 \\
\hline Nordic total & 295 & 1,307 & 341 & 8,620 & 10,267 \\
\hline EU (28) & 5,234 & 23,180 & 5,470 & 152,836 & 181,485 \\
\hline
\end{tabular}





\title{
List of abbreviations
}

\author{
ADHD: Attention Deficit Hyperactivity Disorder \\ ACTH: Adrenocorticotropic hormone \\ AR: Androgen receptor \\ BBP: Benzylbutylphtalate \\ BPR: Biocidal Product Regulation \\ COI: $\quad$ Cost of Illness \\ DBP: Dibutyl Phtalate \\ DEHP: Diethylhexyl Phtalate \\ DES: Diethylstilbestrol \\ DiBP: Di-iso-butyl Phthalate \\ DiNP: Di-iso-nonyl Phthalate \\ DnBP: Di-n-butyl Phthalate \\ DPP: Dipentyl Phtalate \\ EDC: $\quad$ Endocrine Disrupting Compound \\ EINECS: European Inventory of Existing Commercial Chemical Substances \\ EU: European Union \\ ER: Oestrogen receptor \\ GHRH: Growth Hormone Releasing Hormone \\ HEAL: Health and environment alliance \\ ICSI: Intracytoplasmic sperm injection \\ IGF-1: Insulin-like Growth Factor 1 \\ IPCS: International Programme on Chemical Safety \\ IVF: in vitro fertilisation \\ KPP: $\quad$ Cost per patient database (covering Swedish hospital health care) \\ NGO: Non-governmental organisation \\ OECD: Organisation for Economic Co-operation and Development \\ PBDE: Polybrominated Diphenyl Ether \\ PFOA: Perfluorooctanoic acid \\ PFOS: Perfluorooctansulfonic acid \\ PCB: $\quad$ Poly Chlorinated Biphenyl \\ PPP: $\quad$ Plant protection products regulation \\ (Q)SAR: (Quantitative) Structure Activity Relationship \\ REACH: Registration, Evaluation, Authorisation and Restriction of Chemical substances \\ TDS: Testicular dysgenesis syndrome \\ WTP: Willingness to pay \\ WHO: World Health Organisation
}


Nordic Council of Ministers

Ved Stranden 18

DK-1061 Copenhagen K

www.norden.org

\section{The Cost of Inaction}

Exposure to endocrine disruptors(EDs) is suspected to lead to a number of negative effects on human health and for wildlife. In this report the costs for effects on male reproductive health (testicular cancer, hypospadias, cryptorchidism and infertility) are estimated. The model used is built on incidence of disease in the five Nordic countries (Denmark, Finland, Iceland, Norway and Sweden) and cost per case based on cost per patient data from Sweden. Extrapolation to EU28 is made based on population size. Assuming that EDs constitute 2, 20 or $40 \%$ the total costs for the selected health effects are 3.6, 36.1 or 72.3 million Euros/year of exposure in the Nordic countries, this corresponds to 59, 592 and 1,184 million Euros/year at EU-level. As these costs only represent a fraction of the endocrine related diseases there are good reasons to continue the work to minimize exposure to EDs. 